NBER WORKING PAPER SERIES

\title{
TERRORISM AND POLITICAL ATTITUDES: \\ EVIDENCE FROM EUROPEAN SOCIAL SURVEYS
}

\author{
Giovanni Peri \\ Daniel I. Rees \\ Brock Smith \\ Working Paper 28662 \\ http://www.nber.org/papers/w28662 \\ NATIONAL BUREAU OF ECONOMIC RESEARCH \\ 1050 Massachusetts Avenue \\ Cambridge, MA 02138 \\ April 2021
}

We thank Jay Matonte for excellent research assistance and D. Mark Anderson for invaluable comments. The views expressed herein are those of the authors and do not necessarily reflect the views of the National Bureau of Economic Research.

NBER working papers are circulated for discussion and comment purposes. They have not been peer-reviewed or been subject to the review by the NBER Board of Directors that accompanies official NBER publications.

(C) 2021 by Giovanni Peri, Daniel I. Rees, and Brock Smith. All rights reserved. Short sections of text, not to exceed two paragraphs, may be quoted without explicit permission provided that full credit, including $\odot$ notice, is given to the source. 
Terrorism and Political Attitudes: Evidence from European Social Surveys

Giovanni Peri, Daniel I. Rees, and Brock Smith

NBER Working Paper No. 28662

April 2021

JEL No. H56

\begin{abstract}
$\underline{\text { ABSTRACT }}$ nationwide rally-around-the-flag effects.

Giovanni Peri

Department of Economics University of California, Davis

One Shields Avenue

Davis, CA 95616

and NBER

gperi@ucdavis.edu

Daniel I. Rees

Department of Economics

University of Colorado at Denver

Campus Box 181

Denver, CO 80217

and NBER

Daniel.Rees@ucdenver.edu

Brock Smith

Montana State University

brock.smith1@montana.edu
\end{abstract}

Since the turn of the last century, nationalistic political parties have been gaining support in Europe. Over the same period, terror attacks have increased. Using data from European Social Surveys (ESS), we examine the effects of terror attacks involving at least one fatality on attitudes towards immigrants and government institutions. Comparing within-country responses to the ESS shortly before and after fatal terror attacks, we find little evidence of a shift in attitudes against immigrants. Consistent with "rally-around-the flag" effects documented by political scientists, ESS respondents living in the region that was attacked tend to express more trust in parliament and more satisfaction with the national government in the post- as compared to the pre-attack period. Similarly, we find evidence that particularly salient terror attacks can produce 


\section{INTRODUCTION}

Terror attacks in Western Europe have been trending upwards since the mid-2000s, with a notable spike in the years 2014 and 2015 (Figure 1). There were, for instance, an average of 70 terror attacks per year in Western Europe during the period 2004-2007, and an average of 239 attacks per year during the period 2015-2018. This dramatic increase in the frequency of attacks has been cited as evidence that the so-called "international war on terror" is failing (Thrall and Goepner 2017, p. 2).

As terror attacks have become more frequent, nationalistic political parties have also gained support. The center-right Fidesz party, for instance, took over the reins of the Hungarian government in 2010 (Than and Szakacs 2010), and the Eurosceptic Law and Justice party took over the reins of the Polish government in 2015 (Sobczak and Szary 2015); other formerly fringe nationalistic parties have increased their vote shares in Germany, France, the Netherlands, and the United Kingdom (Holleran 2018). Many observers have argued that the recent surge in terrorism has increased anti-immigrant sentiment and reduced support among voters for traditional political parties and government institutions (Smale and Castle 2016; Fekete 2018; Roth 2018; Turak 2018; Neumann 2019), but this argument has not yet been tested using a clean and credible identification strategy.

The goal of this study is to explore the short-run relationship between terror attacks and political attitudes. Drawing on data from the European Social Survey (ESS) for the period 20022019, our focus is on terror attacks that caused at least one fatality and, importantly, occurred exactly at times when the ESS survey was being conducted in the field. Every two years, a new round of the ESS is conducted. The ESS interviews residents of more than 20 countries across Europe on a wide range of topics, including their attitudes towards immigration, the degree to 
which they trust the institutions of government, and their satisfaction with the current national government. Because we know the exact date each interview started, we can compare withincountry responses to the ESS in the weeks before and after a terrorist attack in the country and produce credible estimates of the short-run effects of terror attacks on political attitudes and opinions. Our identifying assumption is that the timing of each interview was quasi-random, so that the pre- versus post-attack comparisons are arguably uncontaminated by secular trends, economic conditions, and other political/social factors that could potentially bias naïve estimates.

Our results provide little support for the hypothesis that terror attacks influence attitudes towards immigration, at least in the short run. The estimated effects on immigration-related responses are, with only a few exceptions, small and statistically insignificant at conventional levels. By contrast, there is evidence that terror attacks affect attitudes towards government institutions. Specifically, we observe sizeable post-attack increases in how much trust ESS respondents have in their parliament and how much satisfaction they have with the national government among respondents living in the region of the country that was attacked. Likewise, high-profile attacks such the Charlie Hebdo shootings in France, are often associated with nationwide and sizeable increases in how much trust ESS respondents have in their parliament, a pattern of results which is consistent with "rally-around-the-flag” effects documented by political scientists (Mueller 1973; MacKuen 1983; Brody 1991; Chowanietz 2011) in the wake of diplomatic or military crises. ${ }^{1}$

There is an ongoing debate as to the effectiveness of terrorism. Studies by Berrebi and Klor (2008), Gould and Klor (2010), and Montalvo (2011, 2012) provide evidence that terror attacks can influence political opinions and alter choices at the ballot box. Other researchers,

\footnotetext{
${ }^{1}$ The sharp increase in popularity of President G.W. Bush after the attacks of September $11^{\text {th }}$, 2001 is, however, considered anecdotally to be a clear example of rallying around the flag in response to a terror attack.
} 
however, have concluded that terrorism has little, if any, impact on political attitudes and election outcomes (Abrahms 2006, 2007, 2012; Lago and Montero 2006; Fortuna 2015; Arvanitidis et al. 2016; Balcells and Torrats-Espinosa 2018; Silva 2018). We view our results, described above, as directly contributing to this debate. Although popular support for European nationalistic and anti-immigration parties has undoubtedly been on the rise in recent decades (Holleran 2018; Roth 2018; Neumann 2019; Peri et al. 2020), our results suggest that terror attacks did not substantially contribute to this phenomenon.

The remainder of this study is organized as follows. We provide a brief review of the literature in the next section. In Section 3, we describe our data. In Section 4, we describe our empirical strategy and report our principal results. Estimates for specific country-round pairs (e.g., estimates based on the responses of French participants immediately before and after the Charlie Hebdo shootings, which occurred while Round 7 of the ESS was in the field) are reported in Section 5. Section 6 concludes.

\section{Previous Studies}

Terror attacks are, by definition, designed to serve political ends (Thornton 1964; Kydd and Walter 2006). There is, however, surprisingly little evidence to suggest that they are actually effective. Studies in this literature typically focus on a particular country and event, limiting their generalizability and leaving questions about their external validity.

For instance, using data from opinion polls conducted in the lead up to parliamentary elections, Gould and Klor (2010) found that terror attacks increased Israelis willingness to grant territorial concessions to the Palestinians as part of a peace agreement. Gould and Klor (2010) also examined whether respondents intended to support the "right-wing bloc" in the upcoming 
elections. Consistent with the results of Berrebi and Klor (2008), they found that terror attacks were associated with a rightward shift in the preferences of Israeli voters. ${ }^{2}$ Although the results of Gould and Klor (2010) are intriguing, it is not clear whether they extend to other counties, time periods, or types of attack.

Silva (2018) used data from the ESS to examine the effects of the Charlie Hebdo shootings, which began on January 7, 2015. Round 7 of the ESS was in the field at the time, allowing Silva to compare responses from the week before and the week after these shootings. The results provide little evidence that French attitudes towards immigrants or refugees or shifted. ${ }^{3}$ By contrast, Finseraas et al. (2011) found that ESS respondents across Europe became more supportive of imposing restrictive immigration policies immediately after the murder of Dutch film-maker Theo van Gogh on November 2, 2004 by a member of a radical Islamist group. $^{4}$

Finally, Brodeur (2018) used county-level data from the United States for the period 1970 -2013 to explore the effect of terror attacks on consumer sentiment and economic outcomes such as employment, earnings, and housing prices. Brodeur's results suggest that terror attacks can

\footnotetext{
${ }^{2}$ These two results (i.e., that terrorism is associated with a greater willingness to make territorial concessions and greater support for right-wing parties) are seemingly at odds. Gould and Klor (2010, p. 1504) explained that they "can be reconciled by the idea that the platforms of the political parties are endogenously changing over time" and pointed to the fact that Likud's platform went from asserting sovereignty over the occupied territories to declaring a willingness to make territorial concessions in exchange for peace.

${ }^{3}$ Specifically, Silva (2018) examined whether ESS respondents thought that France was made better (or worse) by immigrants and whether the government should be generous when judging applications of refugee status. Silva (2018) also examined whether attitudes in other European countries shifted as a result of the Charlie Hebdo shootings. Again, there was little evidence to support this hypothesis.

${ }^{4}$ Finseraas et al. (2011) compared responses to the ESS in 16 countries before and after the murder of Theo van Gogh. A total of 10,376 interviews were conducted in the 27 days before the murder and 9,183 interviews were conducted in the 27 days after the murder. See also and Finseraas and Listhaug (2013) and Legewie (2013).
} 
have powerful and long-lasting economic consequences. Specifically, he found that successful terror attacks decrease employment by 2 percent and decrease housing prices by 1-2 percent. Brodeur (2018) also explored the effects of terror attacks using individual-level data from the Michigan Survey of Consumers (MSC). The results of this exercise lend support to the argument that terror attacks are related to economic outcomes through consumer sentiment. ${ }^{5}$

\section{DATA AND TRENDS}

\subsection{Terror attacks}

Data on terror attacks come from the Global Terrorism Database (GTD), which is housed at the National Consortium for the Study of Terrorism and Responses to Terrorism (START). These data are based on a wide variety of publicly available sources, including newspaper and journal articles, legal documents, and other existing datasets. ${ }^{6}$ They contain detailed information

\footnotetext{
${ }^{5}$ Numerous studies have estimated the effects of terror attacks on election outcomes, as opposed to attitudes or opinions. The results have been decidedly mixed. For instance, Kibris (2010) examined the effects terror attacks carried out by the PKK (i.e., the Kurdistan Workers' Party) on the 1991 and 1995 Turkish general elections. She found a strong positive association between casualties suffered by security forces (police officers and members of the military) and the vote share of right-wing parties. Kirbis concluded that terrorism "led the Turkish people to vote for hard-liners" (Kibris 2010, p. 241). Gassebner et al. (2008) and Balcells and Torrats-Espinosa (2018) examined whether incumbents or challengers benefited from terror attacks but came to opposite conclusions. After analyzing more than 800 elections taking place in 115 countries across the world, Gassebner et al. (2008) found "strong evidence that terrorist attacks increase the probability that the cabinet will be replaced after an election” (p. 129). By contrast, Balcells and Torrats-Espinosa (2018) found that attacks carried out by Euskadi Ta Askatasuna (ETA), a Basque terrorist organization, had no discernable impact on self-reported support for the incumbent party. Perhaps because they occurred just three days before an election, the Madrid train bombings have received a fair amount of attention from past researchers. Bali (2007) and Montalvo (2011, 2012) found that the bombings significantly contributed to the opposition's victory over the incumbent party, while Lago and Montero (2006) concluded that the bombings "have not changed the electoral preferences of Spaniards” (p. 22).

${ }^{6}$ START is a research center at the University of Maryland, College Park. It is dedicated to examining and understanding the causes and consequences of terrorism. See https://www.start.umd.edu/gtd/ for more information on collection methods and the information available in the GDT data.
} 
on each attack, including the date in which it occurred, its location, the number of casualties, and the responsible group. The GTD data have been used by dozens of researchers interested in exploring the causes and consequences of terrorism. ${ }^{7}$

The GTD defines a terror attack as “aimed at attaining a political, economic, religious, or social goal.” Furthermore, there must be evidence that the attack was intended to coerce or send a message to a broad audience (as opposed to the immediate victims). Finally, terror attacks are, according to the GTD, perpetrated by a non-state actor (or actors) and are therefore distinct from "legitimate” warfare activities conducted by national governments or military forces.

Figure 1 shows the number of terror attacks on European soil per year for the period 2000-2018. Since the mid-2000s, terror attacks have been trending upward, with a notable spike in 2014 and 2015 thought to be, at least in part, inspired by the rise of the Islamic State of Iraq and the Levant (ISIL) (Nesser et al. 2016). The number of fatal attacks, defined as attacks involving at least one death, are also shown in Figure $1 .^{8}$ After averaging fewer than 8 per year during the period 2004-2013, terror attacks involving at least one death peaked in 2014, when there were 233.

\subsection{Measuring political attitudes}

To explore the effects of fatal terror attacks on political attitudes among Europeans, we use data from the European Social Survey (ESS). The ESS was launched in 2002. Since then, more than 430,000 respondents from 38 countries have been interviewed in person and asked a battery of questions about their attitudes, behaviors, and values. The ESS is conducted every two

\footnotetext{
${ }^{7}$ See, for example, Choi (2010), Drakos (2010), Gaibulloev and Sandler (2011), Findley and Young (2012), Ding et al. (2017), and Brodeur (2018).

${ }^{8}$ Non-fatal attacks were either aimed at property or were unsuccessful attacks with human targets.
} 
years, although there are changes to the mix of participating countries from round to round. It is considered to be a "model for international surveys" (Jagodzinski and Moschner 2008, p. 475) and has been used by previous researchers interested in estimating the various effects of terrorism (Finseraas and Listhaug 2013; Arvanitidis et al. 2016; Silva 2018; Ahern 2018).

Our immigration-related outcomes are based on responses to three ESS questions. Specifically, the ESS asks respondents whether immigrants make their county "a worse or better place to live," how many immigrants of a different race and/or ethnicity should be allowed in their country, and how many immigrants from "poorer countries outside Europe" should be allowed in their country. Answers to the first question are on a 0-10 scale (where 0 is "worse place to live" and 10 is "better place to live"), while answers to the second and third questions are on a 0-4 scale (where 0 is "allow many to come and live here" and 4 is "allow none").

To gauge whether terror attacks affect attitudes towards government institutions, we use responses to three more ESS questions. Specifically, ESS respondents are asked how much trust they "personally" have in their country's parliament and how much trust they have in the European Parliament. ${ }^{10}$ Answers to these questions are on a $0-10$ scale (where 0 is "no trust at all” and 10 is “complete trust”). The ESS also asks respondents whether they are satisfied with the national government. Answers to this last question are on a $0-10$ scale (where 0 is "extremely dissatisfied" and 10 is "extremely satisfied"). Descriptive statistics for the outcomes used in the analysis are provided in Appendix Table A1.

\footnotetext{
${ }^{9}$ Appendix B shows these questions as they appear on the survey.

${ }^{10}$ We include the question about the European Parliament because the European Union is a frequent target of nationalist and anti-immigration politicians.
} 
As noted in the introduction, our focus is on countries that were attacked while the ESS was conducting its interviews. We begin the empirical analysis by pooling ESS responses from 16 country-round pairs. These country-round pairs (listed in Appendix Table A2) were chosen because the ESS was in the field for at least two weeks before and two weeks after a fatal terror attack, allowing us to leverage within-country variation and estimate what can be characterized as average treatment effects (ATEs). In Section 5, we report separate estimates for each individual country-round pair in our analysis. For instance, France experienced a series of attacks between December 20, 2014 and January 9, 2015, when Round 7 of the ESS was in the field. In Section 5 we report estimates of the effects of this series of attacks on French attitudes towards immigrants and government institutions.

\section{EMPIRICAL METHOdOLOgY AND RESUlts}

Following Depetris-Chauvin et al. (2020), baseline results are obtained by using ordinary least squares (OLS) to estimate the following simple regression model:

$$
y_{i c m t}=\alpha_{0}+\alpha_{1} \text { Post_Attackicmt }+\theta_{\mathrm{m}}+\delta_{c t}+\varepsilon_{i c m},
$$

where $y_{\text {icmt }}$ is one of several outcomes discussed above, $i$ indexes respondents, $c$ indexes country, $m$ indexes calendar month (i.e., January-December), and $t$ indexes ESS rounds. ${ }^{11}$ The independent variable of interest is Post_Attack, equal to 1 if respondent $i$ was interviewed

\footnotetext{
${ }^{11}$ Depetris-Chauvin et al. (2020) examined the relationship between national football team victories and national identity in sub-Saharan Africa. Leveraging within-survey variation, they found that respondents were less likely to identify with their ethnic group immediately following a victory.
} 
after a fatal terror attack occurred and equal to 0 otherwise. Its coefficient, $\alpha_{1}$, measures the change in political attitudes from the pre-attack period (1-14 days before an attack) to the postattack period (0-13 days after an attack). If there were multiple attacks in country $c$ during round $t$, then the pre-attack period is based on the date of the first attack while the post-attack period is based on the date of the last attack. Identification comes from 16 pre- post-attack comparisons. Five out of these 16 comparisons involve multiple attacks. ${ }^{12}$

Month fixed effects $\left(\theta_{\mathrm{m}}\right)$ account for any seasonality in political attitudes. Country-byround fixed effects $\left(\delta_{c t}\right)$ ensure that identification comes from comparing within-country responses from interviews conducted shortly before and after attacks. The identifying assumption is that the timing of each interview was quasi-random, unrelated to the attack or the characteristics of the respondent being interviewed. Standard errors are corrected for clustering at the country-round level to allow for correlation of unobservable individual characteristics within a country-round.

\footnotetext{
${ }^{12}$ For example, there were two fatal terror attacks on German soil when Round 8 of the ESS was in the field. The first of these occurred on October 16, 2016 and the second occurred on December 19, 2016. Using a two-week bandwidth, our sample includes respondents interviewed 1-14 days before the attack on October 16 and those interviewed 0-13 days after the attack on December 19. Respondents interviewed between these two attacks are not included in the analysis. To take another example, there were 5 fatal terror attacks on French soil when Round 7 of the ESS was in the field. The first of these attacks occurred on December 20, 2014 and the last occurred on January 9, 2015. Using a two-week bandwidth, our sample includes respondents interviewed 1-14 days before the attack on December 20 and those interviewed 0-13 days after the attack on January 9. Country-round pairs were included in our analysis only if ESS interviews were conducted in each of the two weeks before the first attack and each of the two weeks after the last attack. Appendix Table A2 contains descriptions of the terror attacks used in our analysis, when they occurred, and the pre- and post-attack periods. Appendix Figures A1 and A2 report interview counts in the pre- and post-treatment periods for each of the 16 country-round pairs that comprise the two-week bandwidth sample.
} 


\subsection{Main Results}

Estimates of $\alpha_{1}$ using a two-week bandwidth sample are reported in the top panel (Panel A) of Table 1. They provide little evidence that terror attacks influence attitudes towards immigrants and government institutions. Without exception, the estimates of $\alpha_{1}$ are small, relative to the mean and statistically insignificant at conventional levels. For instance, experiencing a fatal terror attack is associated with a (statistically insignificant) 0.160 increase in whether respondents believed that immigrants made their country a better place, which is only 3 percent of the mean (5.131).

In the bottom panel (Panel B) of Table 1, we expand the bandwidth to 4 weeks, allowing for the possibility that the effects of terror attacks on political attitudes take more than two weeks to manifest. With this modification, the pre-attack period is 1-28 days before the first terror attack while the post-attack period is 0-27 days after the last. Because we require that the ESS was in the field for at least 4 weeks before the first attack (and 4 weeks after the last), identification is now based on 12, as opposed to 16 , pre- and post-attack comparisons. ${ }^{13}$

Using the 4-week bandwidth, the estimates of $\alpha_{1}$ remain small and statistically insignificant with one interesting exception: experiencing a fatal terror attack is associated with a 0.151 increase in trusting the European Parliament. It should be noted, however, that this estimate is only significant at the 10 percent level and represents a small (3.6 percent) increase relative to the mean response (4.202).

If terror attacks systematically affected who was willing to participate in the EES, the estimates reported in Table 1 may not be reliable. To explore this possibility, we conduct a

\footnotetext{
${ }^{13}$ The country-round pairs that are dropped when we go to from the two- to the 4-week bandwidth are: the Czech Republic-Round 6, Ireland-Round 8, Poland-Round 5, and Spain-Round 4. See Appendix Table A2 for details.
} 
balance test for several respondent characteristics (age, gender, educational attainment, whether the respondent lives in an urban setting, minority status, and whether the respondent was "coping with their current level of income") that, in theory, could be correlated with the outcomes under study. ${ }^{14}$

The results of regressing each of these characteristics on the post-attack dummy and country-by-round fixed effects are reported in Table 2. They suggest that the characteristics of respondents are largely balanced, although a few differences are statistically significant. Using a two-week bandwidth, experiencing a terror attack is associated with a 0.035 increase in the probability that the respondent lived in an urban area and a 0.016 increase in the probability that the respondent self-identified as belonging to a minority group. Using a 4-week bandwidth, experiencing a terror attack is associated with an almost two-year reduction in respondent's age and a 0.35 increase in years of education. It is possible, although unlikely, that these associations are driven by post-attack concerns regarding ESS participation.

To account for these small post-attack changes in the composition of ESS respondents, we augment our estimation equation by including a vector of individual-level characteristics, $\boldsymbol{X} .{ }^{15}$ The augmented version is:

$$
y_{i c m t}=\pi_{0}+\pi_{1} \text { Post Attackicmt }+\boldsymbol{X}_{i c m \boldsymbol{\beta}} \boldsymbol{\beta}+\theta_{\mathrm{m}}+\delta_{c t}+\varepsilon_{i c m t} .
$$

\footnotetext{
${ }^{14}$ Minority status is determined by the question, "Do you belong to a minority ethnic group in [country]?” We code the coping-with-income indicator as equal to 1 if the ESS respondent indicated that he or she was "Coping on present income" or "Living comfortably on present income" in response to the question, "Which of the descriptions comes closest to how you feel about your household's income nowadays?" The coping-with-income indicator is otherwise equal to 0 .

${ }^{15}$ Descriptive statistics for the controls are provided in Appendix Table A3.
} 
Estimates based on (2) are reported in Table 3. Reassuringly, the basic pattern of results remains extremely similar: the estimates of $\pi_{1}$ are small and statistically insignificant. Using a two-week bandwidth, there is a post-attack increase of 0.046 in believing that fewer immigrants of different race/ethnicity should be allowed in the country (Panel A). However, using the 4-week bandwidth, this estimate shrinks to 0.031 and becomes statistically indistinguishable from zero at conventional levels.

\subsection{Event Studies}

Figures 2-7 report event-study estimates of the effects of terror attacks on political attitudes using a 4-week bandwidth. Specifically, these estimates are from a modified version of equation (2) in which the post-attack indicator is replaced with a series of mutually exclusive lead and lag indicators. ${ }^{16}$ This specification allows us to check for pre-treatment trends and to explore whether the effects of terror attacks grew stronger over time. We flexibly estimate the effects of terror attacks before/after one, two, three, and 4 weeks. ${ }^{17}$

Event-study estimates for whether immigrants make the respondent’s country a better place to live are reported in Figure 2. There is no evidence of pre-treatment trends (the estimated coefficients of the pre-event dummies are consistently small and statistically insignificant at conventional levels), but one week after treatment there is a modest tick upwards of 0.098 in how this question was answered, followed by a gradual decline of roughly equal magnitude.

\footnotetext{
${ }^{16}$ We use the 4-week bandwidth sample, which contains 12 country-round pairs. See Appendix Table A2 for details.

${ }^{17}$ Specifically, the zero-week indicator in Figures 2-7 is for interviews that were conducted 0-6 days after the last attack. The one-week indicator is for interviews conducted 7-13 days after the last attack, and so forth. The negative one-week indicator is for interviews conducted 1-7 days before the first attack.
} 
However, none of the post-treatment coefficients are sufficiently precise to reject the hypothesis of zero effect.

Event-study estimates for whether fewer immigrants of different race/ethnicity should be allowed are reported in Figure 3. Although there is no evidence of pre-treatment trends, two weeks after an attack there is a statistically significant 0.122 increase in how this question was answered, or 5.2 percent of the mean response (2.332). To explore whether this estimate reflects a permanent shift in political attitudes, we widen the bandwidth from 4 to 8 weeks. ${ }^{18}$ The results of this exercise are reported in Appendix Figure A3. There is no evidence of a sustained upward trend in the post-attack period, which we interpret as evidence against the hypothesis that attitudes towards immigrants of different races and ethnicities permanently hardened.

The remaining event-study estimates, reported in Figures 4-7, tell a similar story. If using a 4-week bandwidth produces evidence that terror attacks have a modest effect on political attitudes, the estimates based on an 8-week bandwidth, which are reported in Appendix Figures A4-A8, suggest that these effects are, in general, short-lived. ${ }^{19}$

\footnotetext{
${ }^{18}$ In this analysis, we do not require that ESS interviews were conducted in each of the 8 weeks before and after an attack. Instead, we include country-round pairs with any ESS interviews conducted during the 8 weeks before and after an attack and four additional country-round pairs (Hungary-Round 4, Ireland-Round 3, and United Kingdom-Rounds 1 and 7) were included. The results of this analysis should be viewed with caution because each event-study coefficient is based on different within-county comparisons.

${ }^{19}$ Using an 8-week bandwidth, there are small but statistically significant increases in the belief that fewer immigrants from poor countries should be allowed 0, 2 and 3 weeks after an attack (Appendix Figure A5). These estimates range from 0.056 to 0.082 (with p-values of .021 to .027). However, 5 to 7 weeks after an attack, there is a pronounced downward trend in how ESS respondents answered this question, suggesting that any effect of fatal terror attacks on attitudes toward immigrants from poor countries was not only small but impermanent.
} 


\subsection{Regional effects of terror attacks}

Up to this point in the analysis, we have estimated average effects across ESS respondents living in country $c$, the country that was attacked. However, it is possible that attacks are more salient when they occur in the respondent's own region of residence. ESS Rounds 4-9 provide “Nomenclature of Territorial Units for Statistics” (NUTS-1), which allow us to match where an attack occurred with each respondent's region. ${ }^{20}$ While fatal terror attacks typically receive national and even international attention, press coverage is more intense at the regional and local levels. In this section, we use Rounds 4-9 of the ESS to explore the effects of terror attacks on political attitudes at the regional level by estimating the following regression model:

$$
y_{i c r m t}=\pi_{0}+\pi_{1} \text { Post Attack }_{i c m t}+\pi_{2} \text { Post Attackicmt }_{\text {x Region }} \text { Rrmt }+\boldsymbol{X}_{\text {icrmt }} \boldsymbol{\beta}+\theta_{\mathrm{m}}+\delta_{c r t}+\varepsilon_{i c r m t},
$$

where the post-attack indicator is interacted with the variable Region, equal to 1 if the respondent lived in the NUTS-1 region of the country that experienced the attack. ${ }^{21}$ In place of the countryby-round fixed effects used in equations (1) and (2), we include region-by-round fixed effects, $\delta_{\text {crt. }}$

Estimates of equation (3) based on a 4-week bandwidth are reported in Table 4. They provide some evidence that terror attacks can affect political attitudes among residents of the region in which they occur. The direction of these estimated effects is, however, not consistent

\footnotetext{
${ }^{20}$ NUTS regions have three levels, with level 1 being the broadest. We use level 1 because a large portion of ESS observations do not contain information on levels 2 and 3.

${ }^{21}$ The GTD provides the latitude and longitude of terror attacks. Attacks were matched to regions using GIS software.
} 
with the idea that the recent surge in terrorism has weakened faith in government and parliamentary institutions (Smale and Castle 2016; Fekete 2018; Roth 2018; Turak 2018; Neumann 2019). Specifically, estimates of $\pi_{1}$ and $\pi_{2}$ are small and imprecise when attitudes towards immigration are on the left-hand side of the regression. For instance, experiencing a fatal terror attack is associated with a statistically insignificant 0.087 increase $\left(\hat{\pi}_{1}+\hat{\pi}_{2}=\right.$ 0.087) in whether respondents in the affected region believed that immigrants made their country a better place, which is less than 2 percent of the sample mean (5.231). ${ }^{22}$

By contrast, trust in the country's parliament and satisfaction with the national government increase significantly in the affected region (i.e., the region in which the attack occurred). Moreover, these increases appear to be sizable. Specifically, a fatal terror attack is associated with a 0.462 increase in trust in the parliament $\left(\hat{\pi}_{1}+\hat{\pi}_{2}=.462\right)$ and a 0.470 increase in satisfaction with the national government $\left(\hat{\pi}_{1}+\hat{\pi}_{2}=0.470\right)$ in the affected region. The former estimate represents a 10 percent increase relative to the sample mean (4.530), while the latter represents a 12 percent increase relative to the sample mean (3.995). ${ }^{23}$

Why might terror attacks lead residents of the affected region to view government institutions more favorably? Political scientists have described a rally-around-the-flag

\footnotetext{
${ }^{22} \hat{\pi}_{1}$ is statistically significant at the 10 percent level for whether the country should allow fewer immigrants of different race/ethnicity, but the sum of $\hat{\pi}_{1}+\hat{\pi}_{2}(0.077)$ is not statistically distinguishable from zero and is small relative to the mean (2.256).

${ }^{23}$ These estimates of $\hat{\pi}_{1}+\hat{\pi}_{2}$ are statistically significant at the 10 percent level. Affected region eventstudy estimates for trust in parliament and satisfaction with the national government are reported in Appendix Figures A9 and A10. In general, these estimates, although imprecise, confirm that there were sustained post-attack increases in how ESS answered these questions. In Appendix Table A4, we report estimates of equation (3) using a two-week bandwidth. The estimates for trust in parliament and satisfaction with national government are positive but no longer statistically significant at conventional levels, although there is evidence of post-attack increase in the belief that immigrants make the country a better place to live. The estimated effect on the belief that fewer immigrants from poor countries should be allowed is also positive but only significant at the 10 percent level.
} 
phenomenon, in which support for the current government surges in response to some sort of crisis, although their focus has been on military or diplomatic crises (Mueller 1973; MacKuen 1983; Brody 1991; Kuijpers 2019). According to Chowanietz (2011, p. 676) this phenomenon may be a "patriotic reflex" in response to crises that affect the entire nation. ${ }^{24}$ Brody and Shapiro (1989) and Brody (1991) argue that the rallying effect is more likely to occur when there is a dearth of information about the nature of the crisis and opposition leaders are therefore obliged to withhold criticism. In the next section, we provide evidence of rally-around-the-flag responses at the country-round level.

\section{SeParate Estimates by County-Round Pair}

The estimates reported thus far have been based on a pooled sample, potentially masking important heterogeneity. In Tables 5-9, we report separate estimates of $\pi_{1}$ from Equation (2) for each country-round pair in our analysis using 4-week bandwidths. Using two-week bandwidths produced similar results and are reported in Appendix Tables A5-A9. ${ }^{25}$

\footnotetext{
${ }^{24}$ For more information on rally-around-flag effects, see, for instance, Chowanietz (2010) who examined 181 terror attacks occurring in five countries (UK, France, Germany, Spain, USA) during the period 1990-2006. Chowanietz (2010) found that terror attacks were associated with sharp reductions in criticisms of the government by the opposition party and media, which he viewed as evidence of a rallying effect. Brody and Shapiro (1989) found that "elite" criticism of the U.S. government declined in the week following revelations concerning the Iran-Contra scandal in 1986. Analyzing data from 10 OECD countries, Kuijpers (2019) found that the popularity of the governing party increased with casualties during the first year of military interventions.

${ }^{25}$ Month-of-year fixed effects are not included in these regressions due to lack of variation.
} 


\subsection{Terror attacks in Spain.}

In the top panel of Table 5 (Panel A), we focus on two, small-scale fatal terror attacks carried out by the Basque Fatherland and Freedom (ETA) movement when Round 1 of the ESS was in the field. In the first attack occurred on December 17, 2002 and the second occurred on February 8, 2003. These attacks, each of which resulted in the death of a police officer, seem to have reduced trust in the parliament and satisfaction with the national government among Spanish ESS participants. The relevant estimates of $\pi_{1}$ are statistically significant and sizeable. Trust in the parliament was, on average, 0.770 lower in the post-attack period as compared to the pre-attack period (or 16 percent of the mean); satisfaction with the national government was 0.701 lower (or 17 percent of the mean).

In the bottom panel of Table 5 (Panel B), we turn our attention to a bombing at the Madrid airport that occurred when Round 3 of the ESS was in the field. This attack, carried out by ETA, killed two bystanders and wounded 12. It does not seem to have affected trust in parliament or satisfaction with the national government, but attitudes towards immigrants seem to have hardened in the aftermath. ${ }^{26}$ Overall, it is difficult to discern a clear, systematic pattern to how Spaniards reacted to being attacked by ETA. The results reported in Table 5 suggest that each attack elicited distinct reactions, perhaps driven by the particular circumstances of the attack and the steps taken by the Spanish government in the aftermath.

\footnotetext{
${ }^{26}$ The attack is associated with a 0.151 increase in the belief that fewer immigrants of different race/ethnicity should be allowed, which is 6 percent of the mean response (2.54). It is also associated with a 0.159 increase in the belief that fewer immigrants from poorer countries should be allowed, which is 6 percent of the mean response (2.50).
} 


\subsection{Terror attacks in France.}

France experienced a series of 5 terror attacks between December 20, 2014 and January 9, 2015, when Round 7 of the ESS was in the field. Among them, was the attack on the offices of the satirical weekly magazine Charlie Hebdo, in which 12 people were killed and 11 wounded. The Charlie Hebdo attack received intense national and international press coverage and was followed by a sharp rise in anti-Islamic incidents in France (Mondon and Winter 2016; Mechai 2015).

In the top panel of Table 6 (Panel A), we examine the effect of these attacks on political attitudes among French ESS respondents. Similar to the affected-region estimates discussed above (and reported in Table 4), trust in parliament increased by 0.707 in the post-attack period as compared to the pre-attack period; likewise, there was an 0.828 increase in satisfaction with the national government. ${ }^{27}$ These estimates suggest that high-profile terror attacks that result in a substantial number of casualties appreciably strengthen faith in government institutions, at least in the short run.

The attack on French soil during Round 8 was small-scale (only one person was killed) and the perpetrator is still unknown. There is no evidence that it appreciably altered political attitudes (Table 6, Panel B). By contrast, the mass shooting by jihadi-inspired extremists at the Strasbourg Christmas market on December 11, 2018 (while in Round 9 of the ESS was in the field) resulted in 5 deaths, received a great deal of press coverage, and anecdotally caused great

\footnotetext{
${ }^{27}$ These estimated effects are sizeable. The attacks are associated with an increase in trust in parliament of 18 percent relative to the mean $(0.707 / 3.972=0.178)$, and an increase of 28 percent in satisfaction with the national government relative to the mean $(0.828 / 2.93=0.283)$. The attack is also associated with a 0.427 increase in how much trust French respondents had in the European Parliament, or an 11 percent relative to the mean $(0.427 / 3.959=0.108)$. Consistent with the results of Silva $(2018)$, who also used data from the ESS to examine the effects of the Charlie Hebdo shootings, we find little evidence that the attack affected French attitudes towards immigrants.
} 
anxiety among the French (Rubin and Breeden 2018). It does not, however, appear to have affected political attitudes: the estimates of $\pi_{1}$ based on French ESS participants interviewed before and after this attack are consistently insignificant and small in magnitude (Table 6, Panel C).

\subsection{Terror attacks in the United Kingdom.}

The United Kingdom terror attacks used in our analysis were perpetrated by the New Irish Republican Army (IRA) or the Irish National Liberation Army (INLA). Specifically, three attacks took place in Northern Ireland, each resulting in the death of a single civilian. Panel A of Table 7 shows estimates of $\pi_{1}$ for the two attacks that happened in quick succession during Round 6; Panels B and C of Table 7 show estimates of $\pi_{1}$ for the other two attacks. There is no evidence of post-attack changes in how much trust British respondents had in parliament or how much satisfaction they had with the national government. After the attack on October 20, 2016 (during Round 8 of the ESS), there was an increase of 0.097 in the belief that fewer immigrants should be allowed in the country, but there is no evidence of a similar change in attitudes towards immigrants after the other attacks.

\subsection{Terror attacks in the Netherlands}

On November 2, 2004, the filmmaker Theo van Gogh was shot and decapitated by a member of a jihadist group, while Round 2 of the ESS was in the field. This attack received worldwide attention and inspired a series of attacks on mosques in the Netherlands (Finseraas et al. 2011). We also have responses from Round 4 of the ESS before and after a car attack on the 
Dutch royal family. This latter attack occurred on May 1, 2009 and killed 5 festival-goers. The motives of the perpetrator are still unknown.

We find a significant decrease among Dutch respondents in the belief that immigrants make the country better after the murder of Theo van Gogh (Panel A, Table 8). Specifically, our estimate of $\pi_{1}$ is -0.398 , or 8 percent of the mean (4.974). The van Gogh murder also appears to have increased trust in the Dutch parliament as well as trust in the European Parliament, a pattern of results that is consistent with what happened after the Charlie Hebdo shootings. There is no evidence that the May 1, 2009 attack affected political attitudes (Panel C, Table 8).

\subsection{Terror attacks in Germany and Sweden}

Panel A of Table 9 reports estimates of $\pi_{1}$ for two attacks that took place in Germany during Round 8 of the ESS. On October 16 of 2016, a 16-year-old was stabbed to death in Hamburg. Approximately two months later, a truck was driven by a jihadi-inspired extremist into a Berlin Christmas market, leaving 12 bystanders dead and more than 50 injured. Despite the large number of fatalities and intense press coverage (Grieshaber 2016; Hjelmgaard 2016; Stack 2016), these attacks do not seem to have appreciably affected political attitudes among Germans.

Finally, we examine effects on political attitudes in Sweden after an attack carried out while Round 5 of the ESS was in the field. On December 11, 2010, a suicide bomber affiliated with Iraqi extremists attacked a shopping center in Stockholm. Although nobody aside from the bomber was killed, there was a statistically significant and sizeable increase how much trust respondents had in parliament (Table 9, Panel B); there is also evidence of an increase in the belief that immigrants make the country a better place in the post-attack period. 


\section{Conclusion}

This study provides the first comprehensive, multi-country examination of the effects of terror attacks on political opinions and attitudes. Previous studies examining the relationship between terror attacks and similar outcomes have focused on a single event or country and, as a consequence, it is not clear whether their results are generalizable. By comparing within-country responses to the European Social Survey in the weeks before and after terror attacks, we produce arguably causal estimates uncontaminated by secular trends, economic conditions, and other political/social movements and events.

Our results provide little support for the hypothesis that terror attacks involving at least one fatality appreciably shift attitudes towards immigration. With only a few exceptions, the estimated effects on immigrant-related outcomes are small and statistically insignificant. Although we do observe modest post-attack changes in attitudes towards government institutions, these estimated effects are confined to the region in which the attack occurred and they are positive: i.e., experiencing a fatal terror attack is associated with increases in how much trust respondents have in their parliament and how much satisfaction they have with the national government. It is possible that these estimates reflect a rally-around-the-flag phenomenon, in which support for the current government surges in response to some sort of national crisis (Mueller 1973; MacKuen 1983; Brody 1991; Chowanietz 2011).

Finally, when we focus on specific, high-profile attacks, such the Charlie Hebdo shootings in France and the murder of filmmaker Theo van Gogh, we uncover evidence of nationwide rally-around-the-flag effects. Specifically, there was a substantial increase in how much trust French respondents had in their parliament after the Charlie Hebdo shootings. 
Likewise, there were substantial increases in how much trust Dutch ESS respondents had in their own parliament and in the European Parliament after the murder of Theo van Gogh. By contrast, a high-profile attack on a Christmas market perpetrated by a jihadi-inspired extremist does not seem to have appreciably affected political attitudes among Germans.

In recent decades, support for European nationalistic and anti-immigration parties has been on the rise, with nationalistic parties increasing their vote shares in prominent Western European countries such as Germany, France, and the United Kingdom (Holleran 2018). Although observers have speculated that this trend is directly connected to terrorism (Smale and Castle 2016; Fekete 2018; Roth 2018; Turak 2018; Neumann 2019), our results provide no evidence that terror attacks substantially contributed to the changing political views of Europeans. 


\section{REFERENCES}

Abrahms, Max. 2006. “Why Terrorism Does Not Work.” International Security, 31 (2): 42-78.

Abrahms, Max. 2007. "Why Democracies Make Superior Counterterrorists.” Security Studies, 16 (2): 223-253.

Abrahms, Max. 2012. “The Political Effectiveness of Terrorism Revisited.” Comparative Political Studies, 45 (3): 366-393.

Ahern, Kenneth R. 2018. "The Importance of Psychology in Economic Activity: Evidence from Terrorist Attacks.” NBER Working Paper 24331

Arvanitidis, Paschalis, Athina Economou, and Christos Kollias. 2016. “Terrorism's Effects on Social Capital in European Countries.” Public Choice, 169 (3-4): 231-250.

Balcells, Laia and Gerard Torrats-Espinosa. 2018. "Using a Natural Experiment to Estimate the Electoral Consequences of Terrorist Attacks.” Proceedings of the National Academy of Sciences, 115(42): 10624-10629.

Bali, Valentina. 2007. “Terror and Elections: Lessons from Spain.” Electoral Studies, 26 (3): 669-687.

Berrebi, Claude and Esteban F. Klor. 2008. “Are Voters Sensitive to Terrorism? Direct Evidence from the Israeli Electorate.” American Political Science Review, 102(3): 279-301.

Bertrand, Marianne, Esther Duflo and Sendhil Mullainathan. 2004. "How Much Should We Trust Differences-in-Differences Estimates?” Quarterly Journal of Economics, 119(1): 249-276.

Brodeur, Abel. 2018. "The Effect of Terrorism on Employment and Consumer Sentiment: Evidence from Successful and Failed Terror Attacks.” American Economic Journal: Applied Economics, 10 (4): 246-282.

Brody, Richard A. 1991. Assessing the President: The Media, Elite Opinion, and Public Support. Stanford, CA: Stanford University Press.

Brody, Richard A. and Catherine R. Shapiro. 1989. "Policy Failure and Public Support: The Iran-Contra Affair and Public Assessment of President Reagan.” Political Behavior, 11(4): 353369. 
Choi, Seung-Whan. 2010. "Fighting Terrorism through the Rule of Law?” Journal of Conflict Resolution, 54 (6):940-966.

Chowanietz, Christophe. 2011. "Rallying Around the Flag or Railing Against the Government? Political Parties’ Reactions to Terrorist Acts.” Party Politics, 17(5): 673-698.

Depetris-Chauvin, Emilio, Ruben Durante, and Filipe Campante. 2020. "Building Nations through Shared Experiences: Evidence from African Football.” American Economic Review, 110 (5): 1572-1602.

Ding, Fangyu, Quansheng Ge, Dong Jiang, Jingying Fu, and Mengmeng Hao. 2017. "Understanding the Dynamics of Terrorism Events with Multiple-Discipline Datasets and Machine Learning Approach.” PLoS One, 12(6): e0179057.

Drakos, Konstantinos. 2010. “Terrorism Activity, Investor Sentiment, and Stock Returns.” Review of Financial Economics, 19 (3): 128-135.

Fekete, Liz. 2018. Europe's Fault Lines: Racism and the Rise of the Right. New York: Verso.

Finseraas, Henning, Niklas Jakobsson, and Andreas Kotsadam. 2011. "Did the Murder of Theo van Gogh Change Europeans’ Immigration Policy Preferences?’ Kyklos, 64 (3): 396-409.

Finseraas, Henning and Ola Listhaug. 2013. "It Can Happen Here: The Impact of the Mumbai Terror Attacks on Public Opinion in Western Europe.” Public Choice, 156(1-2): 213-228.

Findley, Michael G. and Joseph K. Young. 2012. "More Combatant Groups, More Terror?: Empirical Tests of an Outbidding Logic.” Terrorism and Political Violence, 24(5): 706-721.

Fortna, Virginia Page. 2015. “Do Terrorists Win? Rebels' Use of Terrorism and Civil War Outcomes.” International Organization, 69(3): 519-556.

Gaibulloev, Khusrav and Todd Sandler. 2011. "The Adverse Effect of Transnational and Domestic Terrorism on Growth in Africa.” Journal of Peace Research, 48: (3) 355-371.

Gassebner, Martin, Jong-A-Pin, Richard, and Mierau, Jochen O. 2008. “Terrorism and Electoral Accountability: One strike, You're Out!” Economic Letters,100 (1): 126-129.

Gould, Eric D.and Esteban F. Klor. 2010. “Does Terrorism Work?” Quarterly Journal of Economics, 125 (4)1459-1510.

Grieshaber, Kirsten. 2016. "Germany Checking if Fatal Hamburg Stabbing was IS-Related.” Seattle Times, October 30. Available at: https://www.seattletimes.com/nation-world/germanychecking-if-fatal-hamburg-stabbing-was-is-related/ 
Hjelmgaard, Kim. 2016. "Berlin Christmas Market Attack Suspect was Monitored by Security Services.” USA TODAY, December 22. Available at:

https://www.usatoday.com/story/news/world/2016/12/22/berlin-truck-attackinvestigation/95740162/

Holleran, Max. 2018. “The Opportunistic Rise of Europe’s Far Right.”

The New Republic, February 16. Available at:

https://newrepublic.com/article/147102/opportunistic-rise-europes-far-right

Jagodzinski, Wolfgang and Meinhard Moschner. 2008. “Archiving Poll Data.” In Wolfgang Donsbach and Michael W. Traugott (editors), The Sage Handbook of Public Opinion Research. London: Sage Publications, Ltd., pp. 468-476.

Kibris, Arzu. 2010. "Funerals and Elections: The Effects of Terrorism on Voting Behavior in Turkey.” Journal of Conflict Resolution, 55 (2): 220-247

Kuijpers, Dieuwertje. 2019. "Rally Around All the Flags: The Effect of Military Casualties on Incumbent Popularity in Ten Countries 1990-2014.” Foreign Policy Analysis, 15(3): 392-412.

Kydd, Andrew H. and Barbara F. Walter. 2006. “The Strategies of Terrorism.” International Security, 31 (1): 49-80.

Lago, Ignacio and Jose Ramon Montero. 2006. "The 2004 Election in Spain: Terrorism, Accountability, and Voting.” ICPS Working Paper 253. Available at: file:///C:/Terroist\%20Attacks\%20and\%20Elections/Lago\%20and\%20Montero\%202006.pdf

Legewie, Joscha. 2013. "Terrorist Events and Attitudes Toward Immigrants: A Natural Experiment.” American Journal of Sociology, 118(5):1199-1245

MacKuen, Michael B. 1983. "Political Drama, Economic Conditions, and the Dynamics of Presidential Popularity.” American Journal of Political Science, 27(2): 165-192.

Mechai, Hassina. 2015. "France Sees Rise in Islamophobic Attacks Post Charlie Hebdo: Report" middleeasteye.net, July 7. Available at: https://www.middleeasteye.net/news/france-sees-riseislamophobic-attacks-post-charlie-hebdo-report

Mondon, Aurelien, and Aaron Winter. 2016. "Islamophobia(s) In the aftermath of the Nice Attack.” E-International Relations, June 28. Available at: http://www.e-

ir.info/2016/07/28/islamophobias-in-the-aftermath-of-the-nice-attack/

Montalvo, Jose G. 2011. "Voting after the Bombings: A Natural Experiment on the Effect of Terrorist Attacks on Democratic Elections.” Review of Economics and Statistics, 93(4): 11461154. 
Montalvo, Jose G. 2012. "Re-Examining the Evidence on the Electoral Impact of Terrorist Attacks: The Spanish Election of 2004.” Electoral Studies, 31(1): 96-106

Mueller, John E. 1973. War, Presidents, and Public Opinion. New York: John Wiley \& Sons.

Neumann, Peter R. 2019. "Christchurch and the Rise of the Far Right."

The Washington Post, March 19. Available at:

https://www.washingtonpost.com/politics/2019/03/19/christchurch-rise-far-

right/?noredirect $=$ on\&utm_term $=.4 \mathrm{e} 98250 \mathrm{~d} 3 \mathrm{faf}$

Nesser, Peter, Anne Stenersen, and Emilie Oftedal. 2016. “Jihadi Terrorism in Europe: The ISeffect.” Perspectives on Terrorism, 10(6): 3-24.

Peri, Giovanni, Daniel I. Rees, and Brock Smith. 2020. “Terrorism, Political Opinions, and Election Outcomes: Evidence from Europe.” IZA Discussion Paper 13090, Institute of Labor Economics (IZA).

Roth, Kenneth. 2018. "How to Stand Up for Human Rights in the Age of Trump." Foreign Policy, January 18. Available at: https://foreignpolicy.com/2018/01/18/how-to-standup-for-human-rights-in-the-age-of-trump/

Rubin, Alissa J. and Aurelien Breeden. 2018. "Gunman Traumatizes Strasbourg, Killing at Least 3 in Possible Terror Attack.” New York Times, Dec. 11. Available at:

https://www.nytimes.com/2018/12/11/world/europe/strasbourg-shooting-france.html

Silva, Bruno Castanho. 2018. “The (Non)Impact of the 2015 Paris Terrorist Attacks on Political Attitudes.” Personality and Social Psychology Bulletin, 44(6): 838-850.

Smale, Alison and Stephen Castle. 2016. “Attack in France Fuels Anti-Immigrant Parties on Europe's Right. The New York Times, July 16, 2016. Available at:

https://www.nytimes.com/2016/07/17/world/europe/attack-in-france-fuels-anti-immigrantparties-on-europes-right.html

Sobczak, Pawel and Wiktor Szary. 2015. "Eurosceptics Claim Victory in Landmark Poland Election.” Reuters, World News, October 25. Available at: https://www.reuters.com/article/uspoland-election-idUSKCNOSJ00J20151026

Stack, Liam. 2016. “Deadly Berlin Christmas Market Episode Is Latest in Europe.” New York Times, Dec. 19. Available at: https://www.nytimes.com/2016/12/19/world/europe/europe-terrorattacks-2016.html 
Than, Krisztina and Gergely Szakacs. 2010. "Fidesz Wins Hungary Election with Strong Mandate Reuters, World News, April 11, 2010. Available at: https://www.reuters.com/article/ushungary-election/fidesz-wins-hungary-election-with-strong-mandateidUSTRE63A1GE20100412

Thornton, Thomas Perry. 1964. “Terror as a Weapon of Political Agitation.” In Harry Eckstein, ed., Internal War: Problems and Approaches. New York: Free Press, pp. 71-99.

Thrall, A. Trevor and Erik Goepner. 2017. "Step Back: Lessons for U.S. Foreign Policy from the Failed War on Terror.” Cato Institute Policy Analysis No. 814. Available at:

https://www.cato.org/publications/policy-analysis/step-back-lessons-us-foreign-policy-failedwar-terror

Turak, Natasha. 2018. "The Future of Europe’s Elections will be all about Migration, Foreign Minister Says.” CNBC, June 1. Available at:

https://www.cnbc.com/2018/06/01/the-future-of-europes-elections-will-be-all-aboutmigration.html 
Table 1. Fatal Terror Attacks and Political Attitudes

\begin{tabular}{|c|c|c|c|c|c|c|}
\hline & $\begin{array}{c}\text { Immigrants } \\
\text { make country } \\
\text { better }\end{array}$ & $\begin{array}{l}\text { Fewer } \\
\text { immigrants of } \\
\text { different } \\
\text { race/ethnicity }\end{array}$ & $\begin{array}{c}\text { Fewer } \\
\text { immigrants from } \\
\text { poorer countries }\end{array}$ & $\begin{array}{c}\text { Trust in } \\
\text { country's } \\
\text { parliament }\end{array}$ & $\begin{array}{l}\text { Satisfied with } \\
\text { national } \\
\text { government }\end{array}$ & $\begin{array}{c}\text { Trust in } \\
\text { European } \\
\text { Parliament }\end{array}$ \\
\hline \multicolumn{7}{|l|}{ Panel A: Two-week bandwidth } \\
\hline \multirow[t]{2}{*}{ Post attack } & $\begin{array}{c}.160 \\
(.104) \\
{[7445]}\end{array}$ & & $\begin{array}{c}.008 \\
(.024) \\
{[7472]}\end{array}$ & $\begin{array}{c}.068 \\
(.089) \\
{[7515]}\end{array}$ & $\begin{array}{l}-.007 \\
(.086) \\
{[7524]}\end{array}$ & $\begin{array}{c}.093 \\
(.114) \\
{[7039]}\end{array}$ \\
\hline & & $\begin{array}{l}(.025) \\
{[7456]}\end{array}$ & & & & \\
\hline Mean of dep. var. & 5.171 & 2.353 & 2.402 & 4.356 & 4.049 & 4.304 \\
\hline \multicolumn{7}{|l|}{ Panel B: Four-week bandwidth } \\
\hline \multirow[t]{3}{*}{ Post attack } & .102 & -.013 & -.028 & .115 & -.030 & $.151^{*}$ \\
\hline & $(.110)$ & $(.035)$ & $(.025)$ & $(.115)$ & $(.126)$ & $(.074)$ \\
\hline & [11298] & [11205] & [11235] & [11251] & [11292] & [10616] \\
\hline Mean of dep. var. & 5.131 & 2.312 & 2.379 & 4.605 & 4.126 & 4.202 \\
\hline Country-by-round fixed effects & yes & yes & yes & yes & yes & yes \\
\hline Individual controls & no & no & no & no & no & no \\
\hline
\end{tabular}

*Statistically significant at $10 \%$ level; ** at 5\% level; *** at $1 \%$ level.

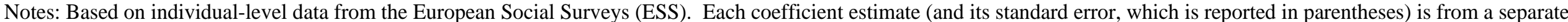

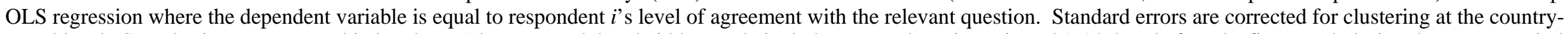

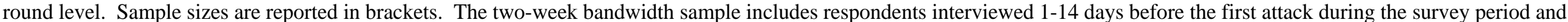

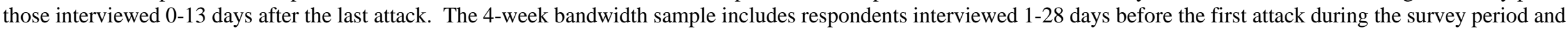

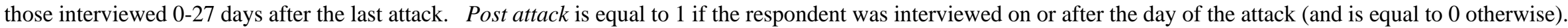

Regressions include country-by-round fixed effects and month-of-year fixed effects. 
Table 2. Balance in Covariates

\begin{tabular}{|c|c|c|c|}
\hline Covariate & Observations & Mean & $\begin{array}{c}\text { Estimated coefficient of } \\
\text { Post Attack } \\
\end{array}$ \\
\hline \multicolumn{4}{|l|}{ Panel A: Two-week bandwidth } \\
\hline Age & 7692 & 46.25 & $\begin{array}{l}-1.444 \\
(0.945)\end{array}$ \\
\hline Male & 7725 & 0.49 & $\begin{array}{c}0.028 \\
(0.016)\end{array}$ \\
\hline Years of education & 7544 & 12.63 & $\begin{array}{c}0.206 \\
(0.137)\end{array}$ \\
\hline Urban & 7725 & 0.63 & $\begin{array}{l}0.035^{*} \\
(0.018)\end{array}$ \\
\hline Minority & 7725 & 0.05 & $\begin{array}{l}0.016^{* * *} \\
(0.004)\end{array}$ \\
\hline Coping with current level of income & 7725 & 0.79 & $\begin{array}{c}0.004 \\
(0.012)\end{array}$ \\
\hline \multicolumn{4}{|l|}{ Panel B: Four-week bandwidth } \\
\hline Age & 11513 & 46.80 & $\begin{array}{l}-1.843^{* *} \\
(0.718)\end{array}$ \\
\hline Male & 11557 & 0.49 & $\begin{array}{l}0.019 * \\
(0.010)\end{array}$ \\
\hline Years of education & 11316 & 12.66 & $\begin{array}{l}0.348 *^{*} \\
(0.118)\end{array}$ \\
\hline Urban & 11557 & 0.64 & $\begin{array}{c}0.042 \\
(0.024)\end{array}$ \\
\hline Minority & 11557 & 0.06 & $\begin{array}{c}0.004 \\
(0.005)\end{array}$ \\
\hline Coping with current level of income & 11557 & 0.83 & $\begin{array}{c}0.010 \\
(0.010)\end{array}$ \\
\hline
\end{tabular}

*Statistically significant at $10 \%$ level; ** at $5 \%$ level; *** at $1 \%$ level.

Notes: Based on individual-level data from the European Social Surveys (ESS). Each coefficient estimate (and its standard error, which is reported in parentheses) is from a separate OLS regression where the dependent variable is equal to the relevant covariate. The two-week bandwidth sample includes respondents interviewed 1-14 days before the first attack during the survey period and those interviewed 0-13 days after the last attack. The 4-week bandwidth sample includes respondents interviewed 1-28 days before the first attack during the survey period and those interviewed 0-27 days after the last attack. In Panel A, the analysis is restricted to observations used in any of the 6 regressions reported in Panel A of Table 1. In Panel B, the analysis is restricted to observations used in any of the 6 regressions reported in Panel B of Table 1. Post attack is equal to 1 if the respondent was interviewed on or after the day of the attack (and is equal to 0 otherwise). Regressions include country-by-round fixed effects. 
Table 3. Fatal Terror Attacks and Political Attitudes: Including Individual-Level Controls

\begin{tabular}{|c|c|c|c|c|c|c|}
\hline & $\begin{array}{c}\text { Immigrants } \\
\text { make country } \\
\text { better }\end{array}$ & $\begin{array}{c}\text { Fewer } \\
\text { immigrants of } \\
\text { different } \\
\text { race/ethnicity }\end{array}$ & $\begin{array}{c}\text { Fewer } \\
\text { immigrants from } \\
\text { poorer countries }\end{array}$ & $\begin{array}{c}\text { Trust in } \\
\text { country's } \\
\text { parliament }\end{array}$ & $\begin{array}{c}\text { Satisfied with } \\
\text { national } \\
\text { government }\end{array}$ & $\begin{array}{c}\text { Trust in } \\
\text { European } \\
\text { Parliament } \\
\end{array}$ \\
\hline \multicolumn{7}{|l|}{ Panel A: Two-week bandwidth } \\
\hline Post attack & $\begin{array}{c}.093 \\
(.107) \\
{[7265]}\end{array}$ & $\begin{array}{l}.046^{* *} \\
(.021) \\
{[7281]}\end{array}$ & $\begin{array}{c}.032 \\
(.018) \\
{[7295]}\end{array}$ & $\begin{array}{c}.054 \\
(.089) \\
{[7330]}\end{array}$ & $\begin{array}{l}-.015 \\
(.076) \\
{[7333]}\end{array}$ & $\begin{array}{c}.033 \\
(.102) \\
{[6867]}\end{array}$ \\
\hline Mean of dep. var. & 5.188 & 2.348 & 2.399 & 4.369 & 4.046 & 4.311 \\
\hline \multicolumn{7}{|l|}{ Panel B: Four-week bandwidth } \\
\hline Post attack & $\begin{array}{c}.005 \\
(.092) \\
{[11056]}\end{array}$ & $\begin{array}{c}.031 \\
(.027) \\
{[10967]}\end{array}$ & $\begin{array}{c}.018 \\
(.023) \\
{[10995]}\end{array}$ & $\begin{array}{c}.080 \\
(.101) \\
{[11000]}\end{array}$ & $\begin{array}{c}-.040 \\
(.120) \\
{[11037]}\end{array}$ & $\begin{array}{c}.069 \\
(.064) \\
{[10384]}\end{array}$ \\
\hline Mean of dep. var. & 5.139 & 2.309 & 2.378 & 4.615 & 4.120 & 4.203 \\
\hline $\begin{array}{l}\text { Country-by-round fixed effects } \\
\text { Individual controls }\end{array}$ & $\begin{array}{l}\text { yes } \\
\text { yes }\end{array}$ & $\begin{array}{l}\text { yes } \\
\text { yes }\end{array}$ & $\begin{array}{l}\text { yes } \\
\text { yes }\end{array}$ & $\begin{array}{l}\text { yes } \\
\text { yes }\end{array}$ & $\begin{array}{l}\text { yes } \\
\text { yes }\end{array}$ & $\begin{array}{l}\text { yes } \\
\text { yes }\end{array}$ \\
\hline
\end{tabular}

*Statistically significant at $10 \%$ level; ** at $5 \%$ level; *** at $1 \%$ level.

Notes: Based on individual-level data from the European Social Surveys (ESS). Each coefficient estimate (and its standard error, which is reported in parentheses) is from a separate OLS regression where the dependent variable is equal to respondent $i$ 's level of agreement with the relevant question. Standard errors are corrected for clustering at the countryround level. Sample sizes are reported in brackets. The two-week bandwidth sample includes respondents interviewed 1-14 days before the first attack during the survey period and those interviewed 0-13 days after the last attack. The 4-week bandwidth sample includes respondents interviewed 1-28 days before the first attack during the survey period and those interviewed 0-27 days after the last attack. Post attack is equal to 1 if the respondent was interviewed on or after the day of the attack (and is equal to 0 otherwise).

Regressions include country-by-round and month-of-year fixed effects, respondents' age, gender, years education, an indicator for living in an urban area, an indicator for minority status, and an indicator for respondent coping at current income level. 
Table 4. Post-Attack Attitudes in the Region of the Attack

\begin{tabular}{|c|c|c|c|c|c|c|}
\hline & $\begin{array}{l}\text { Immigrants } \\
\text { make country } \\
\text { better }\end{array}$ & $\begin{array}{c}\text { Fewer } \\
\text { immigrants of } \\
\text { different } \\
\text { race/ethnicity }\end{array}$ & $\begin{array}{c}\text { Fewer } \\
\text { immigrants from } \\
\text { poorer countries }\end{array}$ & $\begin{array}{c}\text { Trust in } \\
\text { country's } \\
\text { parliament }\end{array}$ & $\begin{array}{l}\text { Satisfied with } \\
\text { national } \\
\text { government }\end{array}$ & $\begin{array}{c}\text { Trust in } \\
\text { European } \\
\text { Parliament }\end{array}$ \\
\hline Post attack & $\begin{array}{c}-.046 \\
(.088)\end{array}$ & $\begin{array}{l}.058^{*} \\
(.030)\end{array}$ & $\begin{array}{c}.040 \\
(.027)\end{array}$ & $\begin{array}{c}.002 \\
(.076)\end{array}$ & $\begin{array}{l}-.085 \\
(.104)\end{array}$ & $\begin{array}{r}-.051 \\
(.092)\end{array}$ \\
\hline Post attack $*$ Region & $\begin{array}{c}.133 \\
(.112)\end{array}$ & $\begin{array}{c}.019 \\
(.072)\end{array}$ & $\begin{array}{c}.075 \\
(.045)\end{array}$ & $\begin{array}{l}.460^{*} \\
(.231)\end{array}$ & $\begin{array}{l}.555^{* *} \\
(.213)\end{array}$ & $\begin{array}{c}.373 \\
(.361)\end{array}$ \\
\hline $\begin{array}{l}\mathrm{N} \\
\text { Mean of dep. var. }\end{array}$ & $\begin{array}{l}8149 \\
5.231\end{array}$ & $\begin{array}{l}8090 \\
2.256\end{array}$ & $\begin{array}{l}8113 \\
2.341\end{array}$ & $\begin{array}{l}8143 \\
4.529\end{array}$ & $\begin{array}{l}8136 \\
3.995\end{array}$ & $\begin{array}{l}7780 \\
3.971\end{array}$ \\
\hline $\begin{array}{l}\text { Country-by-round fixed effects } \\
\text { Individual controls }\end{array}$ & $\begin{array}{l}\text { yes } \\
\text { yes }\end{array}$ & $\begin{array}{l}\text { yes } \\
\text { yes }\end{array}$ & $\begin{array}{l}\text { yes } \\
\text { yes }\end{array}$ & $\begin{array}{l}\text { yes } \\
\text { yes }\end{array}$ & $\begin{array}{l}\text { yes } \\
\text { yes }\end{array}$ & $\begin{array}{l}\text { yes } \\
\text { yes }\end{array}$ \\
\hline
\end{tabular}

*Statistically significant at $10 \%$ level; ** at $5 \%$ level; *** at $1 \%$ level.

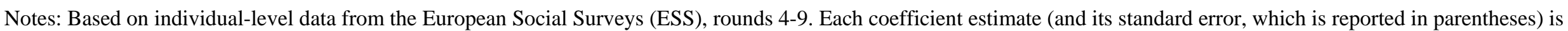

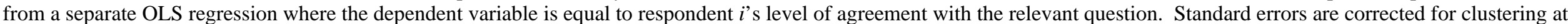

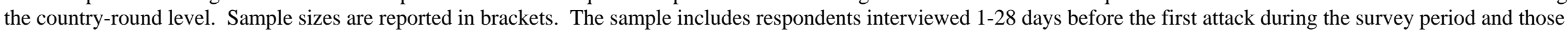

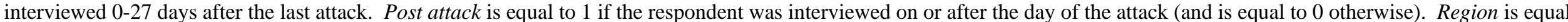

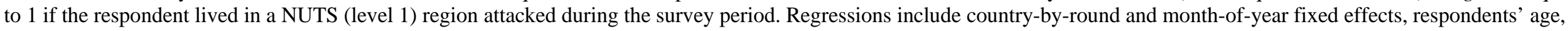
gender, years education, an indicator for living in an urban area, an indicator for minority status, and an indicator for respondent coping at current income level. 
Table 5. Individual Country-Round Results: Spain

\begin{tabular}{|c|c|c|c|c|c|c|}
\hline & $\begin{array}{l}\text { Immigrants make } \\
\text { country better }\end{array}$ & $\begin{array}{c}\text { Fewer immigrants } \\
\text { of different } \\
\text { race/ethnicity }\end{array}$ & $\begin{array}{c}\text { Fewer immigrants } \\
\text { from poorer } \\
\text { countries }\end{array}$ & $\begin{array}{c}\text { Trust in country's } \\
\text { parliament }\end{array}$ & $\begin{array}{l}\text { Satisfied with } \\
\text { national } \\
\text { government }\end{array}$ & $\begin{array}{c}\text { Trust in European } \\
\text { Parliament }\end{array}$ \\
\hline \multicolumn{7}{|c|}{ Panel A: Spain Round 1} \\
\hline \multirow[t]{3}{*}{ Post attack } & 0.121 & 0.107 & 0.046 & $-.770^{* * *}$ & $-.701^{* * *}$ & -0.372 \\
\hline & -0.21 & -0.09 & -0.087 & -0.278 & -0.249 & -0.268 \\
\hline & [1133] & [1108] & [1118] & [1110] & [1155] & [1041] \\
\hline Mean of dep. var. & 4.765 & 2.3782 .378 & 2.402 & 4.795 & 4.198 & 4.789 \\
\hline \multicolumn{7}{|c|}{ Panel B: Spain Round 3} \\
\hline \multirow[t]{3}{*}{ Post attack } & -0.052 & $.151^{* *}$ & $.159^{* *}$ & -0.036 & -0.277 & 0.041 \\
\hline & -0.167 & -0.065 & -0.066 & -0.191 & -0.184 & -0.188 \\
\hline & [859] & [853] & {$[853]$} & {$[829]$} & {$[833]$} & {$[754]$} \\
\hline Mean of dep. var. & 4.7924 .929 & 2.537 & 2.504 & 5.034 & 4.752 & 5.114 \\
\hline
\end{tabular}

*Statistically significant at $10 \%$ level; ** at $5 \%$ level; *** at $1 \%$ level.

Notes: Based on individual-level data from the European Social Surveys (ESS). Each coefficient estimate is from a separate OLS regression where the dependent variable is equal to respondent $i$ 's level of agreement with the relevant question. Huber-White robust standard errors are reported in parentheses. The sample includes respondents interviewed 1-28 days before the first attack during the survey period and those interviewed 0-27 days after the last attack. Post attack is equal to 1 if the respondent was interviewed on or after the day of the attack (and is equal to 0 otherwise). Regressions include respondents' age, gender, years education, an indicator for living in an urban area, an indicator for minority status, and an indicator for respondent coping at current income level. 
Table 6. Individual Country-Round Results: France

\begin{tabular}{|c|c|c|c|c|c|c|}
\hline & $\begin{array}{c}\text { Immigrants make } \\
\text { country better }\end{array}$ & $\begin{array}{c}\text { Fewer immigrants } \\
\text { of different } \\
\text { racelethnicity }\end{array}$ & $\begin{array}{c}\text { Fewer immigrants } \\
\text { from poorer } \\
\text { countries }\end{array}$ & $\begin{array}{c}\text { Trust in country's } \\
\text { parliament }\end{array}$ & $\begin{array}{c}\text { Satisfied with } \\
\text { national } \\
\text { government }\end{array}$ & $\begin{array}{c}\text { Trust in European } \\
\text { Parliament }\end{array}$ \\
\hline \multicolumn{7}{|c|}{ Panel A: France Round 7} \\
\hline \multirow[t]{3}{*}{ Post attack } & 0.14 & -0.061 & -0.079 & $.707^{* * *}$ & $.828^{* * *}$ & $.427^{*}$ \\
\hline & -0.19 & -0.065 & -0.07 & -0.205 & -0.192 & -0.232 \\
\hline & [1418] & [1404] & [1417] & [1416] & {$[1421]$} & [1387] \\
\hline Mean of dep. var. & 4.792 & 2.389 & $\begin{array}{l}2.564 \\
2.564\end{array}$ & 3.972 & 2.930 & 3.959 \\
\hline \multicolumn{7}{|c|}{ Panel B: France Round 8} \\
\hline \multirow[t]{3}{*}{ Post attack } & -0.111 & 0.024 & 0.042 & 0.2 & 0.055 & 0.017 \\
\hline & -0.137 & -0.054 & -0.056 & -0.158 & -0.141 & -0.15 \\
\hline & [1553] & [1541] & [1548] & [1558] & [1554] & [1525] \\
\hline Mean of dep. var. & 4.903 & 2.331 & 2.361 & 4.213 & 3.205 & 3.833 \\
\hline \multicolumn{7}{|c|}{ Panel c: France Round 9} \\
\hline \multirow[t]{3}{*}{ Post attack } & -0.029 & 0.083 & 0.101 & -0.056 & 0.297 & 0.282 \\
\hline & -0.169 & -0.069 & -0.075 & -0.216 & -0.237 & -0.217 \\
\hline & [788] & {$[780]$} & {$[780]$} & [788] & [794] & {$[775]$} \\
\hline Mean of dep. var. & 5.087 & 2.228 & 2.283 & 4.034 & 3.485 & 4.010 \\
\hline
\end{tabular}

*Statistically significant at $10 \%$ level; ** at 5\% level; *** at $1 \%$ level.

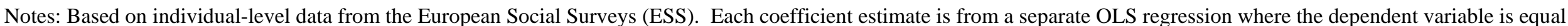

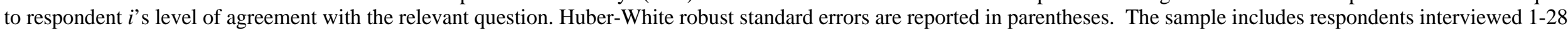

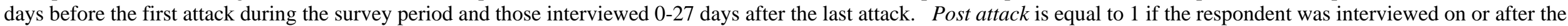

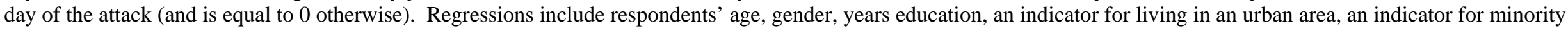
status, and an indicator for respondent coping at current income level. 
Table 7. Individual Country-Round Results: United Kingdom

\begin{tabular}{|c|c|c|c|c|c|c|}
\hline & $\begin{array}{c}\text { Immigrants make } \\
\text { country better }\end{array}$ & $\begin{array}{c}\text { Fewer immigrants } \\
\text { of different } \\
\text { race/ethnicity }\end{array}$ & $\begin{array}{c}\text { Fewer immigrants } \\
\text { from poorer } \\
\text { countries } \\
\end{array}$ & $\begin{array}{c}\text { Trust in country's } \\
\text { parliament }\end{array}$ & $\begin{array}{c}\text { Satisfied with } \\
\text { national } \\
\text { government }\end{array}$ & $\begin{array}{c}\text { Trust in European } \\
\text { Parliament }\end{array}$ \\
\hline \multicolumn{7}{|c|}{ Panel A: UK Round 6} \\
\hline \multirow[t]{3}{*}{ Post attack } & 0.096 & -0.042 & 0.012 & 0.19 & 0.174 & -0.044 \\
\hline & -0.168 & -0.059 & -0.066 & -0.173 & -0.172 & -0.17 \\
\hline & {$[984]$} & {$[982]$} & {$[981]$} & {$[978]$} & {$[986]$} & {$[851]$} \\
\hline Mean of dep. var. & 4.828 & 2.528 & 2.656 & 4.245 & 3.993 & 3.421 \\
\hline \multicolumn{7}{|c|}{ Panel B: UK Round 8} \\
\hline \multirow[t]{3}{*}{ Post attack } & -0.164 & $.097^{* *}$ & 0.052 & -0.135 & -0.228 & -0.098 \\
\hline & -0.135 & -0.049 & -0.052 & -0.152 & -0.148 & -0.151 \\
\hline & [1317] & [1302] & [1304] & [13222.298 ] & [1310] & [1266] \\
\hline Mean of dep. var. & 5.647 & 2.212 & 2.298 & 4.665 & 4.681 & 3.729 \\
\hline \multicolumn{7}{|c|}{ Panel c: UK Round 9} \\
\hline \multirow[t]{3}{*}{ Post attack } & -0.049 & 0.095 & 0.114 & -0.213 & -0.324 & -0.121 \\
\hline & -0.33 & -0.1 & -0.103 & -0.313 & -0.341 & -0.347 \\
\hline & [382] & [380] & {$[381]$} & [382] & {$[378]$} & {$[370]$} \\
\hline Mean of dep. var. & 6.016 & 2.074 & 2.163 & 4.385 & 3.689 & 3.76 \\
\hline
\end{tabular}

*Statistically significant at $10 \%$ level; ** at $5 \%$ level; *** at $1 \%$ level.

Notes: Based on individual-level data from the European Social Surveys (ESS). Each coefficient estimate is from a separate OLS regression where the dependent variable is equal to respondent i's level of agreement with the relevant question. Huber-White robust standard errors are reported in parentheses. The sample includes respondents interviewed 1-28 days before the first attack during the survey period and those interviewed 0-27 days after the last attack. Post attack is equal to 1 if the respondent was interviewed on or after the day of the attack (and is equal to 0 otherwise). Regressions include respondents' age, gender, years education, an indicator for living in an urban area, an indicator for minority status, and an indicator for respondent coping at current income level. 
Table 8. Individual Country-Round Results: the Netherlands

\begin{tabular}{|c|c|c|c|c|c|c|}
\hline & $\begin{array}{c}\text { Immigrants make } \\
\text { country better }\end{array}$ & $\begin{array}{c}\text { Fewer immigrants } \\
\text { of different } \\
\text { race/ethnicity }\end{array}$ & $\begin{array}{c}\text { Fewer immigrants } \\
\text { from poorer } \\
\text { countries }\end{array}$ & $\begin{array}{c}\text { Trust in country's } \\
\text { parliament }\end{array}$ & $\begin{array}{l}\text { Satisfied with } \\
\text { national } \\
\text { government } \\
\end{array}$ & $\begin{array}{c}\text { Trust in Europeal } \\
\text { Parliament } \\
\end{array}$ \\
\hline \multicolumn{7}{|c|}{ Panel A: Netherlands Round 2} \\
\hline \multirow{3}{*}{ Post attack } & $-.398^{* *}$ & -0.001 & 0.008 & $.252^{*}$ & 0.071 & $.261^{*}$ \\
\hline & -0.161 & -0.065 & -0.069 & -0.151 & -0.156 & -0.158 \\
\hline & [915] & {$[916]$} & {$[911]$} & {$[918]$} & [913] & [809] \\
\hline Mean of dep. var. & 4.974 & 2.485 & 2.563 & 4.776 & 4.559 & 4.816 \\
\hline \multicolumn{7}{|c|}{ Panel B: Netherlands Round 4} \\
\hline \multirow[t]{3}{*}{$\overline{\text { Post attack }}$} & 0.159 & -0.028 & -0.07 & 0.401 & 0.166 & -0.201 \\
\hline & -0.308 & -0.126 & -0.121 & -0.285 & -0.277 & -0.36 \\
\hline & {$[268]$} & {$[264]$} & [264] & [269] & {$[270]$} & {$[258]$} \\
\hline Mean of dep. var. & 4.985 & 2.312 & 2.384 & 5.543 & 5.342 & 4.69 \\
\hline
\end{tabular}

*Statistically significant at $10 \%$ level; ** at $5 \%$ level; *** at $1 \%$ level.

Notes: Based on individual-level data from the European Social Surveys (ESS). Each coefficient estimate is from a separate OLS regression where the dependent variable is equal to respondent $i$ 's level of agreement with the relevant question. Huber-White robust standard errors are reported in parentheses. The sample includes respondents interviewed 1-28 days before the first attack during the survey period and those interviewed 0-27 days after the last attack. Post attack is equal to 1 if the respondent was interviewed on or after the day of the attack (and is equal to 0 otherwise). Regressions include respondents' age, gender, years education, an indicator for living in an urban area, an indicator for minority status, and an indicator for respondent coping at current income level. 


\section{Table 9. Individual Country-Round Results: Germany and Sweden}

\begin{tabular}{|c|c|c|c|c|c|c|}
\hline & $\begin{array}{c}\text { Immigrants make } \\
\text { country better }\end{array}$ & $\begin{array}{c}\text { Fewer immigrants } \\
\text { of different } \\
\text { race/ethnicity }\end{array}$ & $\begin{array}{l}\text { Fewer immigrants } \\
\text { from poorer } \\
\text { countries }\end{array}$ & $\begin{array}{l}\text { Trust in country's } \\
\text { parliament }\end{array}$ & $\begin{array}{l}\text { Satisfied with } \\
\text { national } \\
\text { government }\end{array}$ & $\begin{array}{c}\text { Trust in Europea } \\
\text { Parliament }\end{array}$ \\
\hline \multicolumn{7}{|c|}{ Panel A: Germany Round 8} \\
\hline \multirow[t]{3}{*}{ Post attack } & -0.092 & 0.016 & 0.031 & -0.077 & 0.209 & -0.23 \\
\hline & -0.162 & -0.065 & -0.067 & -0.196 & -0.164 & -0.175 \\
\hline & [878] & [878] & [877] & [871] & [871] & [855] \\
\hline Mean of dep. var. & 5.277 & 2.079 & 2.133 & 5.135 & 4.928 & 4.344 \\
\hline \multicolumn{7}{|c|}{ Panel B: Sweden Round 5} \\
\hline \multirow[t]{3}{*}{ Post attack } & $.435^{*}$ & -0.059 & -0.026 & $.497^{* *}$ & -0.076 & -0.014 \\
\hline & -0.25 & -0.082 & -0.082 & -0.211 & -0.257 & -0.254 \\
\hline & [1418] & [559] & {$[561]$} & [559] & {$[552]$} & [493] \\
\hline Mean of dep. var. & 6.681 & 1.753 & 1.775 & 6.307 & 6.07 & 5.066 \\
\hline
\end{tabular}

*Statistically significant at $10 \%$ level; ** at 5\% level; *** at $1 \%$ level.

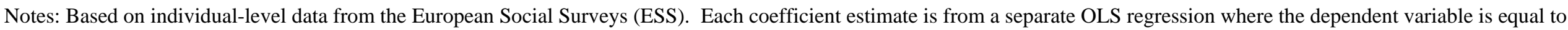

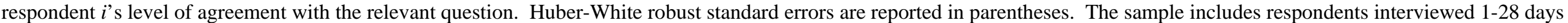

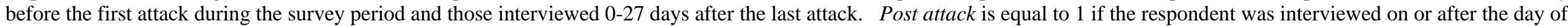

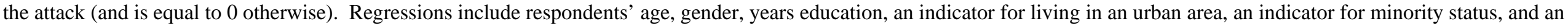
indicator for respondent coping at current income level. 


\section{Figure 1. Terror Attack Trends in Western Europe, 2000-2018}

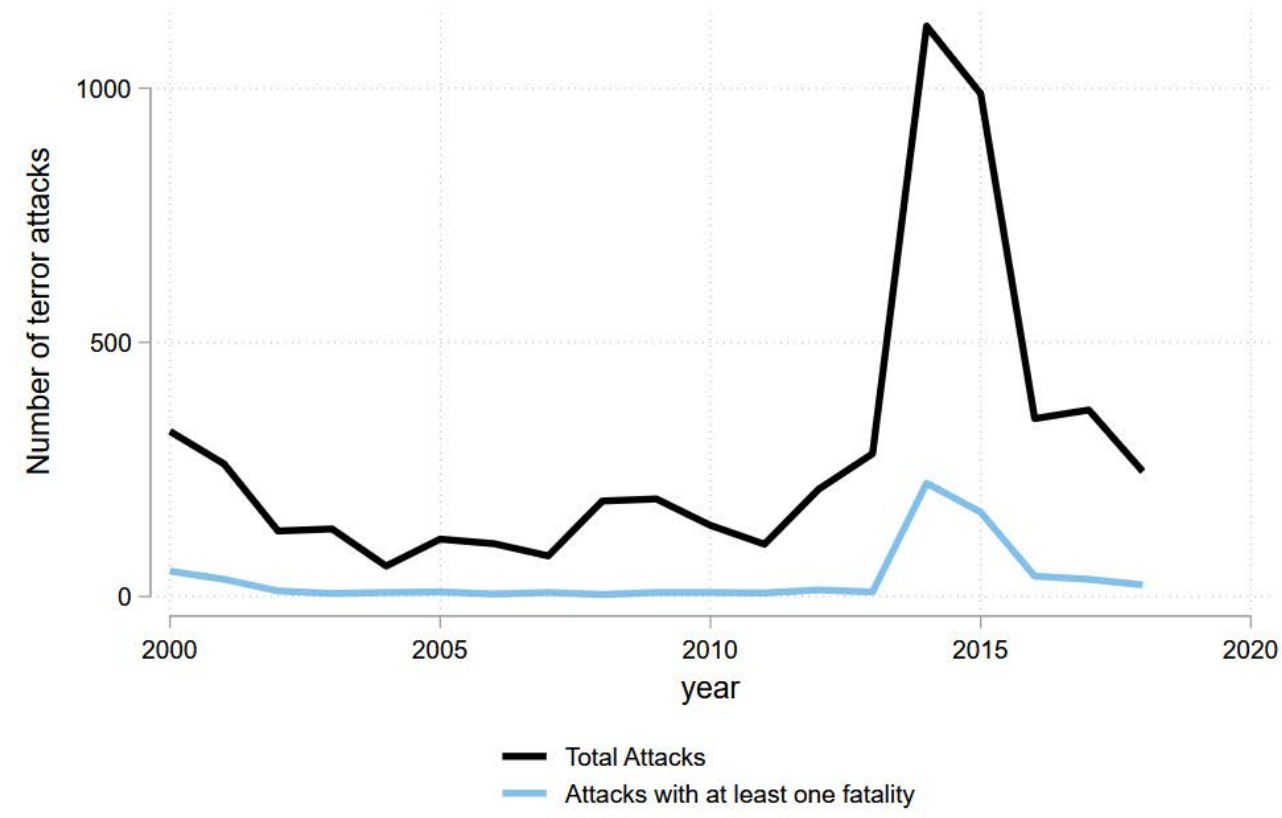

Notes: This figure shows the total number of terror attacks and the number of fatal terror attacks occurring in countries that participated in the European Social Survey, excluding Israel, Turkey and Russia. Data on terror attacks comes from the Global Terrorism Database (GTD) and pertain to the period 2000-2018 


\section{Figure 2. Event Study Estimates: Fatal Terror Attacks and "Immigrants Make Country Better Place to Live”}

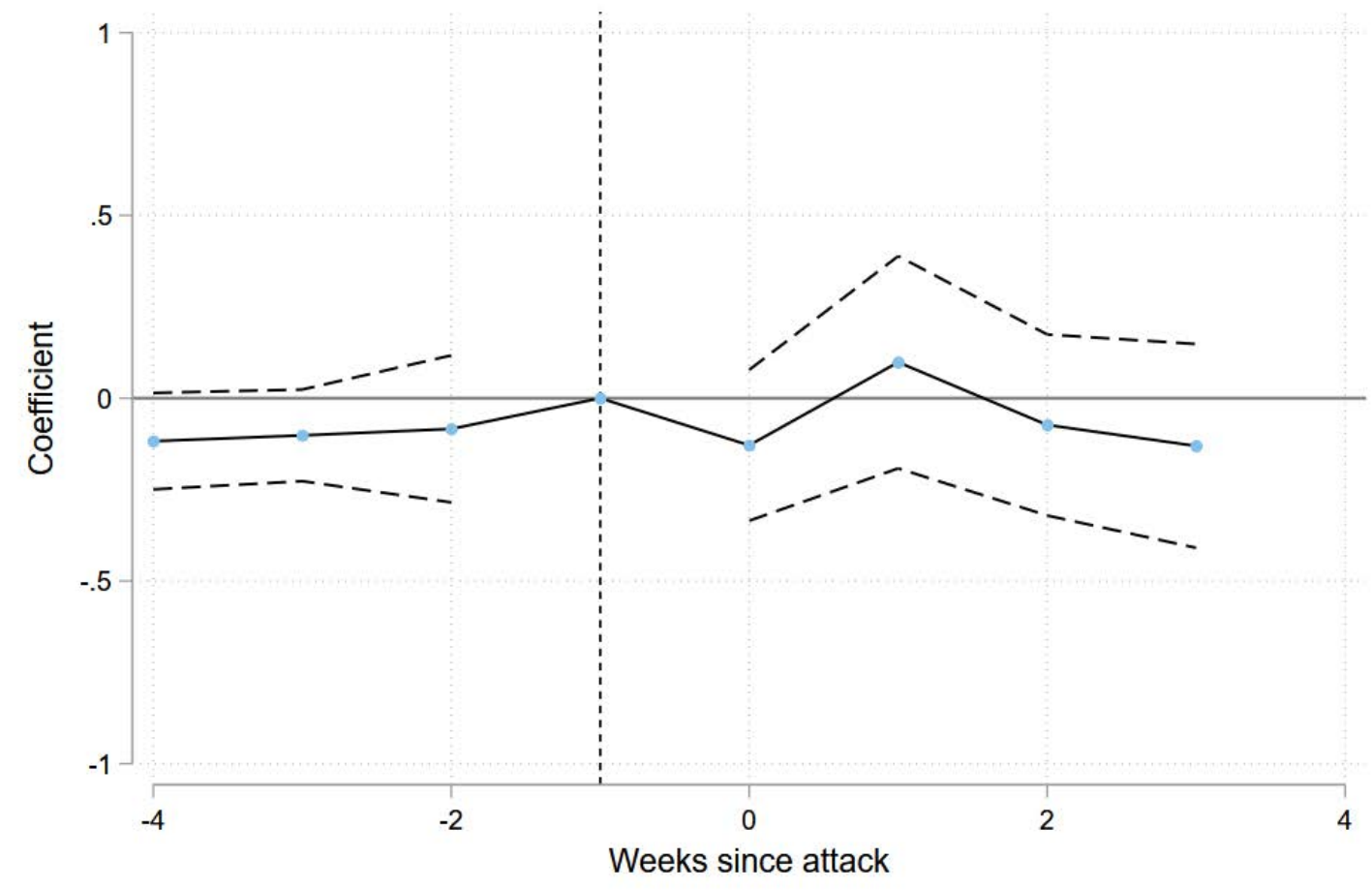

Notes: Based on individual-level data from the European Social Surveys (ESS). Figure plots coefficient estimates for weeks-since-attack indicators as described in the text, along with $90 \%$ confidence intervals. The sample includes respondents interviewed 1-28 days before the first attack during the survey period and respondents interviewed 0-27 days after the last attack. Regressions include country-by-round and month-of-year fixed effects, and control for respondents' age, gender, years education, an indicator for living in an urban area, an indicator for minority status, and an indicator for respondent coping at current income level. 


\section{Figure 3. Event Study Estimates: Fatal Terror Attacks and “Allow Fewer Immigrants of Different Race/Ethnicity”}

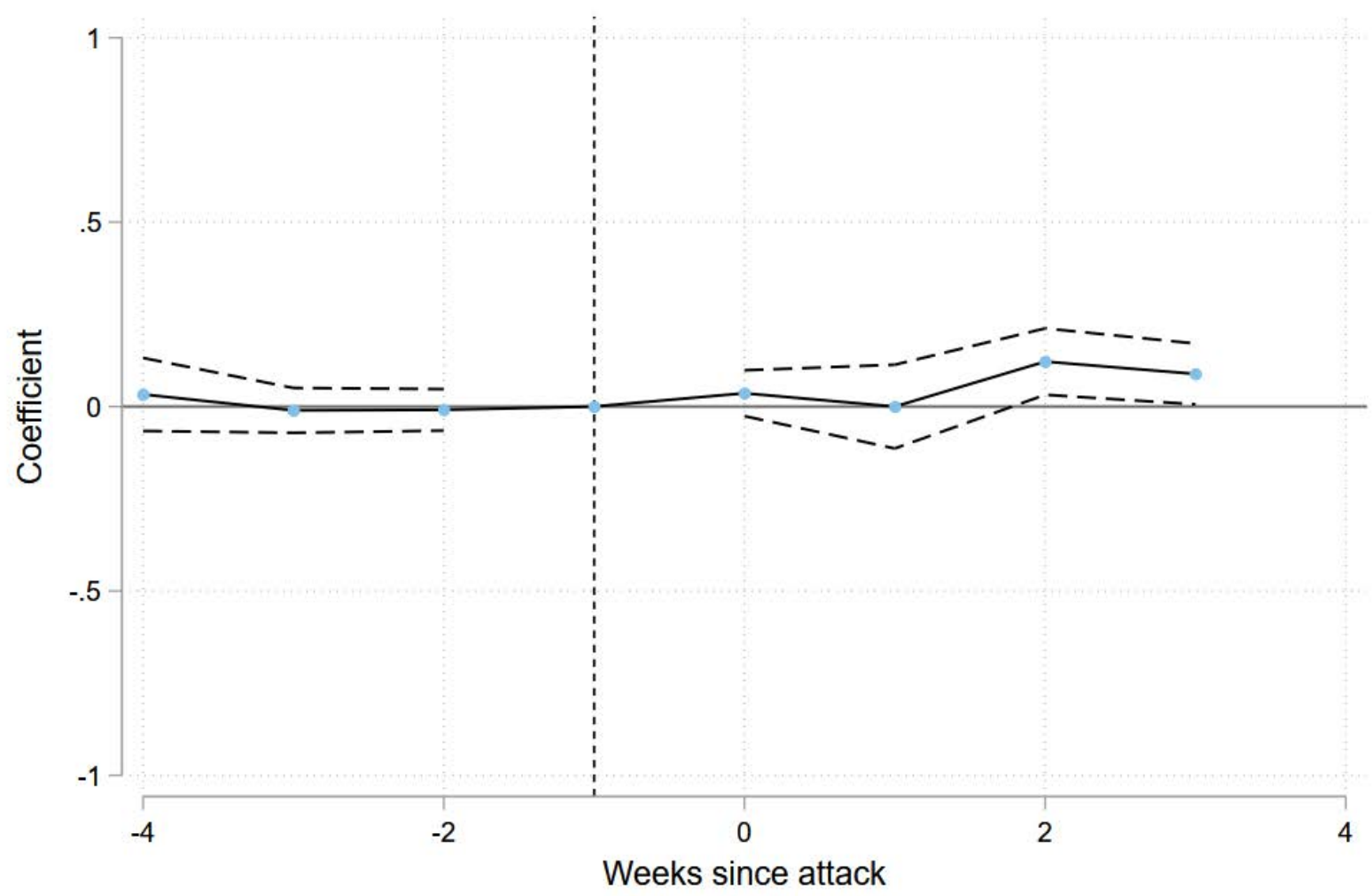

Notes: Based on individual-level data from the European Social Surveys (ESS). Figure plots coefficient estimates for weeks-since-attack indicators as described in the text, along with $90 \%$ confidence intervals. The sample includes respondents interviewed 1-28 days before the first attack during the survey period and respondents interviewed 0-27 days after the last attack. Regressions include country-by-round and month-of-year fixed effects, and control for respondents' age, gender, years education, an indicator for living in an urban area, an indicator for minority status, and an indicator for respondent coping at current income level. 


\section{Figure 4. Event Study Estimates: Fatal Terror Attacks and “Allow Fewer Immigrants from Poorer Countries"}

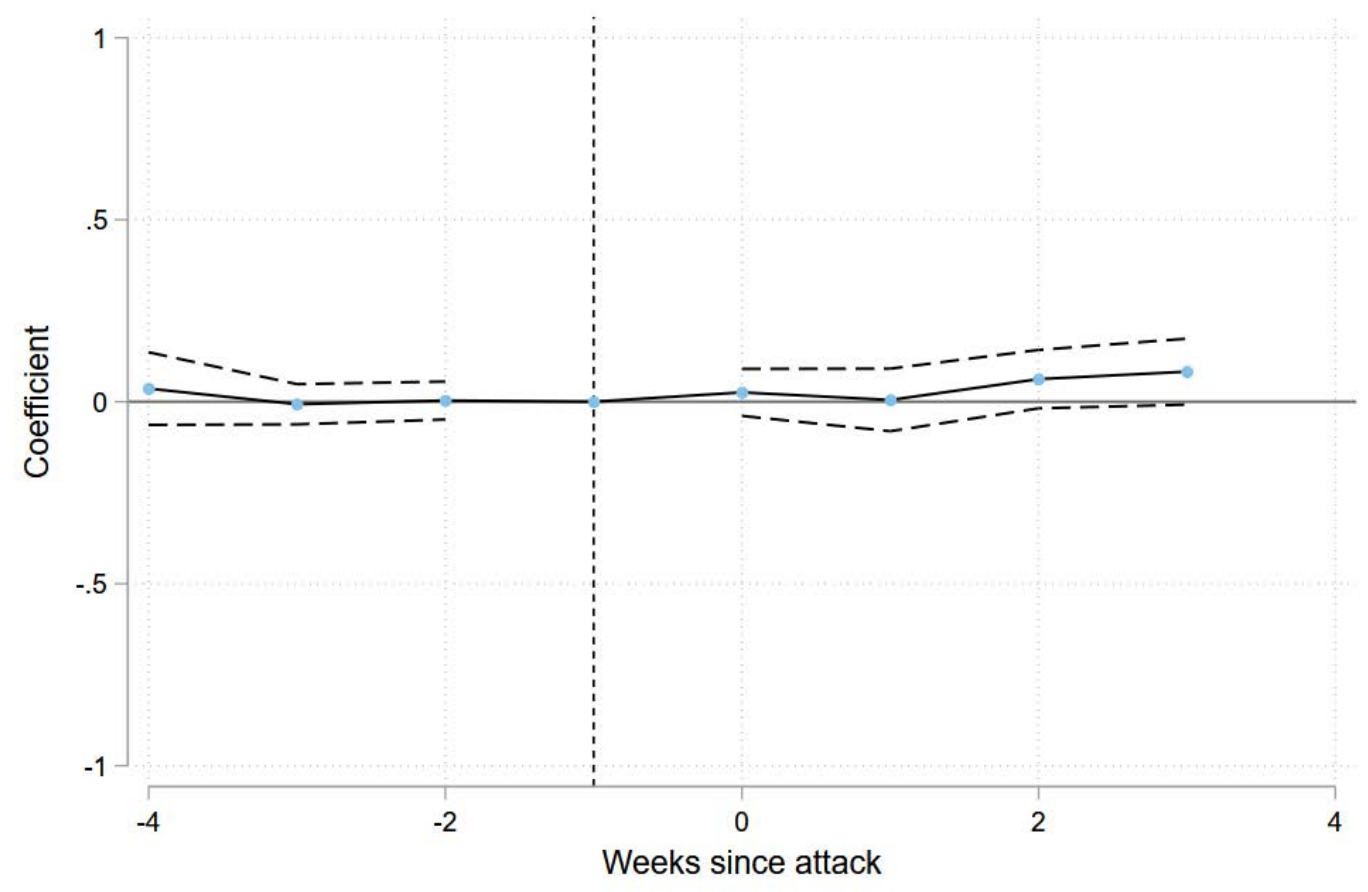

Notes: Based on individual-level data from the European Social Surveys (ESS). Figure plots coefficient estimates for weeks-since-attack indicators as described in the text, along with $90 \%$ confidence intervals. The sample includes respondents interviewed 1-28 days before the first attack during the survey period and respondents interviewed 0-27 days after the last attack. Regressions include country-by-round and month-of-year fixed effects, and control for respondents' age, gender, years education, an indicator for living in an urban area, an indicator for minority status, and an indicator for respondent coping at current income level. 


\section{Figure 5. Event Study Estimates: Fatal Terror Attacks and "Trust in Country's Parliament”}

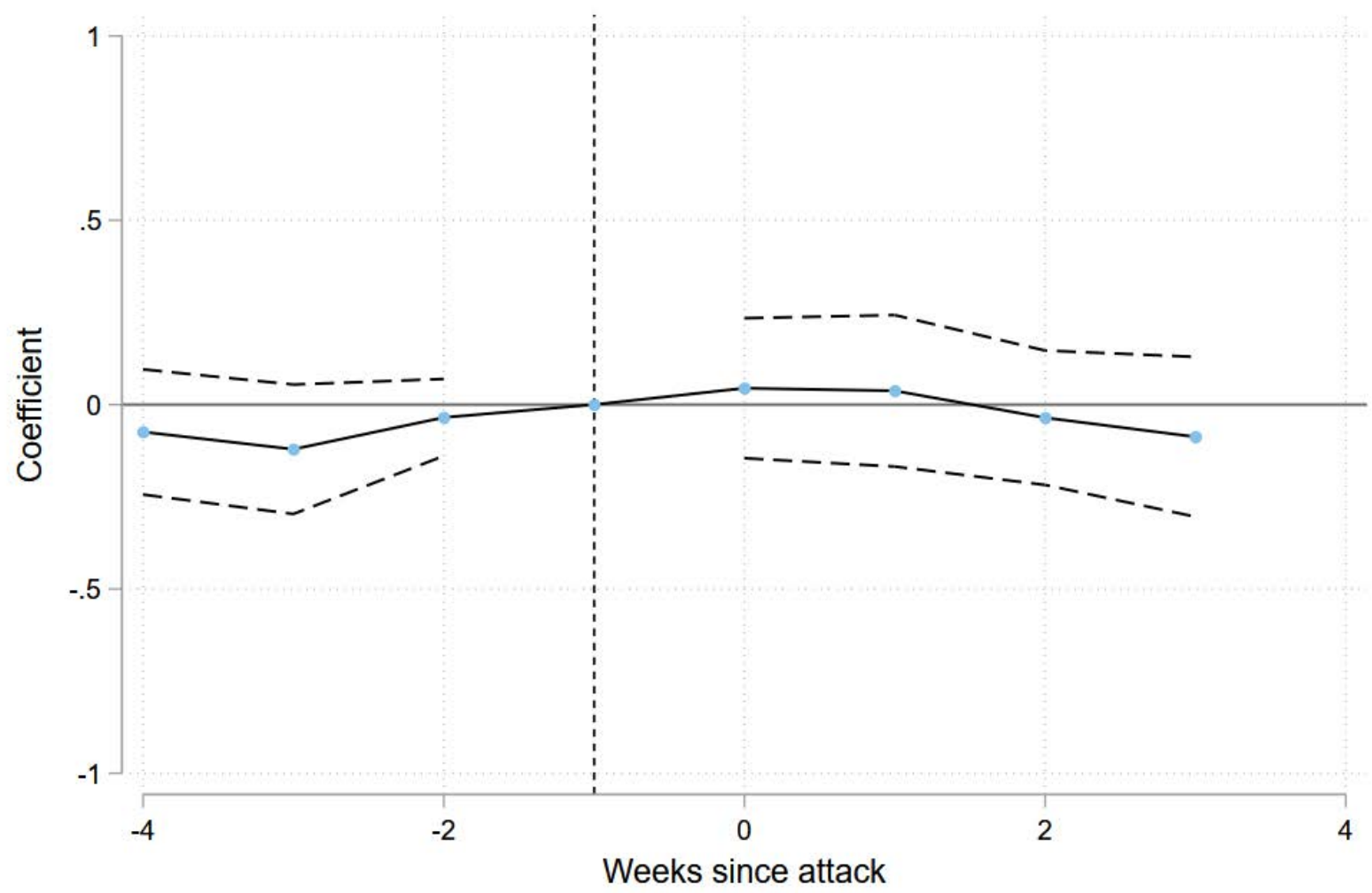

Notes: Based on individual-level data from the European Social Surveys (ESS). Figure plots coefficient estimates for weeks-since-attack indicators as described in the text, along with $90 \%$ confidence intervals. The sample includes respondents interviewed 1-28 days before the first attack during the survey period and respondents interviewed 0-27 days after the last attack. Regressions include country-by-round and month-of-year fixed effects, and control for respondents' age, gender, years education, an indicator for living in an urban area, an indicator for minority status, and an indicator for respondent coping at current income level. 


\section{Figure 6. Event Study Estimates: Fatal Terror Attacks and "How Satisfied with National Government"}

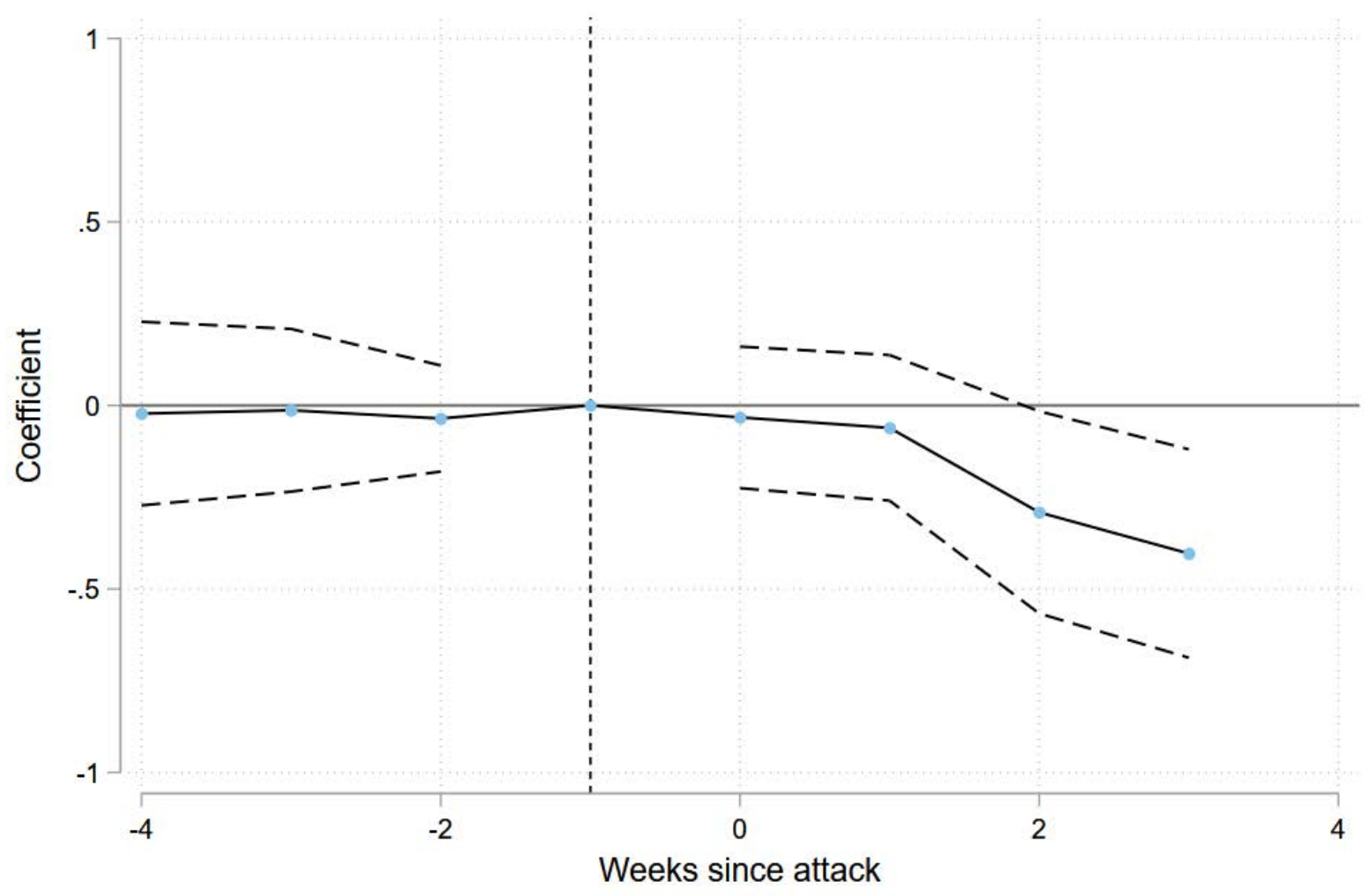

Notes: Based on individual-level data from the European Social Surveys (ESS). Figure plots coefficient estimates for weeks-since-attack indicators as described in the text, along with $90 \%$ confidence intervals. The sample includes respondents interviewed 1-28 days before the first attack during the survey period and respondents interviewed 0-27 days after the last attack. Regressions include country-by-round and month-of-year fixed effects, and control for respondents' age, gender, years education, an indicator for living in an urban area, an indicator for minority status, and an indicator for respondent coping at current income level. 


\section{Figure 7. Event Study Estimates: Fatal Terror Attacks and "Trust in European Parliament”}

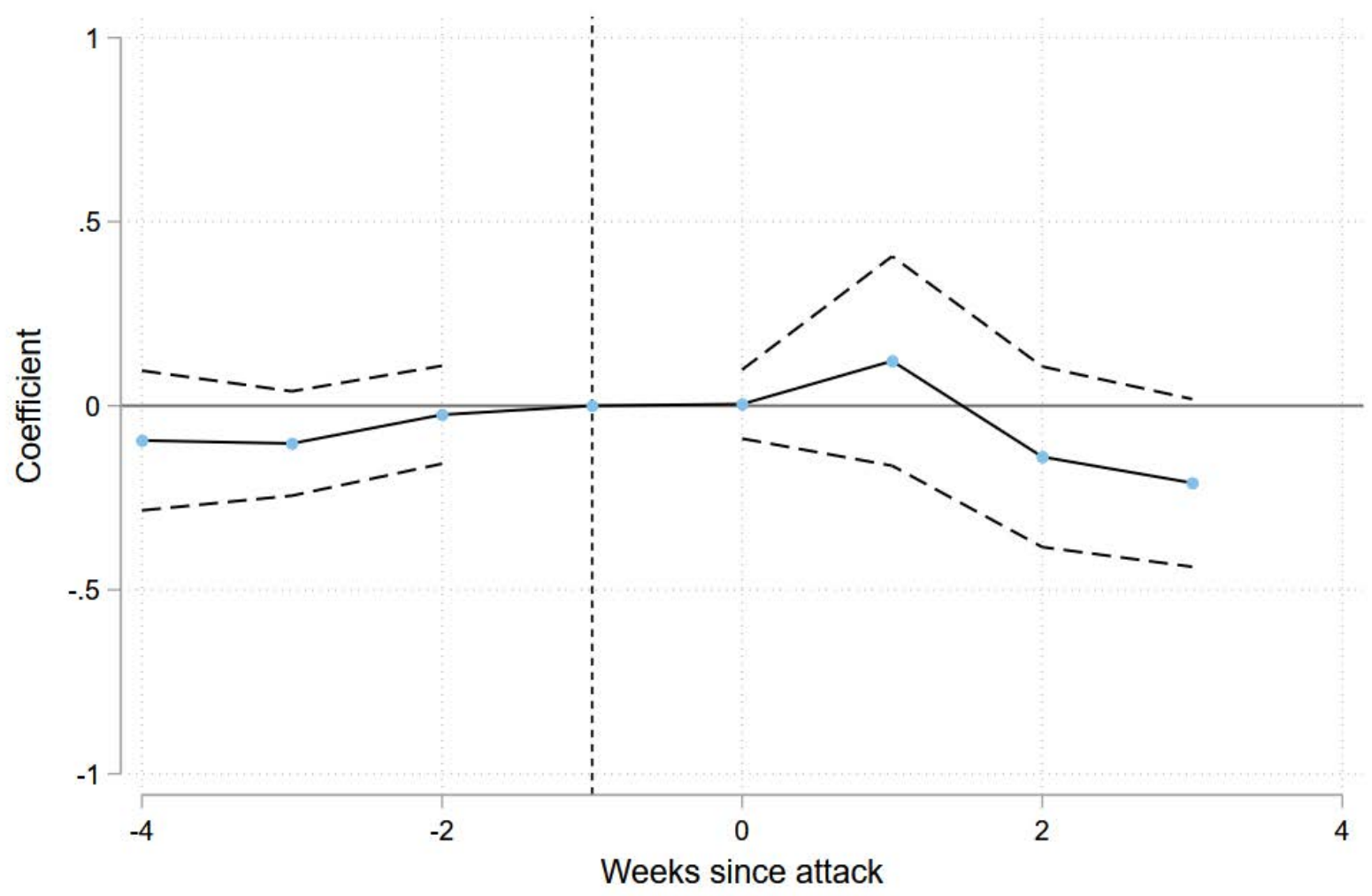

Notes: Based on individual-level data from the European Social Surveys (ESS). Figure plots coefficient estimates for weeks-since-attack indicators as described in the text, along with $90 \%$ confidence intervals. The sample includes respondents interviewed 1-28 days before the first attack during the survey period and respondents interviewed 0-27 days after the last attack. Regressions include country-by-round and month-of-year fixed effects, and control for respondents' age, gender, years education, an indicator for living in an urban area, an indicator for minority status, and an indicator for respondent coping at current income level. 


\section{ApPendix A. AdDitional tables AND Figures}

\section{Table A1. ESS Outcome Descriptive Statistics}

\begin{tabular}{|c|c|c|}
\hline & $\begin{array}{c}\text { Mean } \\
(\mathrm{SD})\end{array}$ & Description \\
\hline $\begin{array}{l}\text { Immigrants make country better } \\
\text { place to live }\end{array}$ & $\begin{array}{c}5.07 \\
(2.25) \\
{[11,056]}\end{array}$ & $\begin{array}{l}\text { Integer responses from } 0-10.0=\text { "Worse place to live." } 10= \\
\text { "Better place to live." }\end{array}$ \\
\hline $\begin{array}{l}\text { Should allow fewer immigrants } \\
\text { of different race/ ethnicity }\end{array}$ & $\begin{array}{c}2.33 \\
(.849) \\
{[10,967]}\end{array}$ & $\begin{array}{l}1=\text { "Allow many to come and live here." } 2=\text { "Allow some." } 3= \\
\text { "Allow a few." } 4=\text { "Allow none." }\end{array}$ \\
\hline $\begin{array}{l}\text { Should allow fewer immigrants } \\
\text { from poorer countries }\end{array}$ & $\begin{array}{c}2.41 \\
(.885) \\
{[10,995]}\end{array}$ & $\begin{array}{l}1=\text { "Allow many to come and live here." } 2=\text { "Allow some." } 3= \\
\text { "Allow a few." } 4=\text { "Allow none." }\end{array}$ \\
\hline Trust in country's parliament & $\begin{array}{c}4.59 \\
(2.38) \\
{[11,000]}\end{array}$ & $\begin{array}{l}\text { Integer responses from } 0-10.0=\text { "No trust at all." } 10= \\
\text { "Complete Trust." }\end{array}$ \\
\hline $\begin{array}{l}\text { How satisfied with the national } \\
\text { government }\end{array}$ & $\begin{array}{c}4.09 \\
(2.36) \\
{[11,037]}\end{array}$ & $\begin{array}{l}\text { Integer responses from } 0-10.0=\text { "Extremely dissatisfied." } 10= \\
\text { "Extremely satisfied." }\end{array}$ \\
\hline $\begin{array}{l}\text { Trust in the European } \\
\text { Parliament }\end{array}$ & $\begin{array}{c}4.13 \\
(2.39) \\
{[10,384]}\end{array}$ & $\begin{array}{l}\text { Integer responses from } 0-10.0=\text { "No trust at all." } 10= \\
\text { "Complete Trust." }\end{array}$ \\
\hline
\end{tabular}

Notes: Unweighted means are reported (with standard deviations in parentheses and sample size in brackets). Includes observations from the relevant regression in our preferred 4-week bandwidth specification results from Table 4. Based on individual-level data from the European Social Surveys (ESS), 2002-2019. 
Table A2. Terror Attacks

\begin{tabular}{|c|c|c|c|c|c|c|c|c|}
\hline Country & $\begin{array}{l}\text { ESS } \\
\text { Round }\end{array}$ & $\begin{array}{l}\text { In 4-week } \\
\text { bandwidth } \\
\text { analysis? }\end{array}$ & $\begin{array}{l}\text { Number of } \\
\text { attacks }\end{array}$ & $\begin{array}{l}\text { Number of } \\
\text { fatalities }\end{array}$ & $\begin{array}{l}\text { Date of } \\
\text { first attack }\end{array}$ & $\begin{array}{l}\text { Date of } \\
\text { last attack }\end{array}$ & Perpetrators & Description \\
\hline $\begin{array}{c}\text { Czech } \\
\text { Republic }\end{array}$ & 6 & no & 1 & 1 & $1 / 19 / 2013$ & $1 / 19 / 2013$ & unknown & $\begin{array}{l}\text { Suicide bomb attack in Ceske Velenice. } \\
\text { Only the bomber was killed }\end{array}$ \\
\hline France & 7 & yes & 5 & 21 & $12 / 20 / 2014$ & $1 / 9 / 2015$ & $\begin{array}{l}\text { Al-Qaida, other } \\
\text { Jihadi-inspired } \\
\text { extremists }\end{array}$ & $\begin{array}{l}\text { Series of attacks including the Charlie } \\
\text { Hebdo attack. }\end{array}$ \\
\hline France & 8 & yes & 1 & 1 & $12 / 16 / 2016$ & $12 / 16 / 2016$ & unknown & $\begin{array}{l}\text { Arson attack on migrant shelter in which } \\
13 \text { were wounded. }\end{array}$ \\
\hline France & 9 & yes & 1 & 5 & $12 / 11 / 2018$ & $12 / 11 / 2018$ & $\begin{array}{c}\text { Jihadi-inspired } \\
\text { extremists }\end{array}$ & $\begin{array}{l}\text { Mass shooting at Strasbourg Christmas } \\
\text { market. }\end{array}$ \\
\hline Germany & 8 & yes & 2 & 14 & $10 / 16 / 2016$ & $12 / 19 / 2016$ & $\begin{array}{l}\text { Two by Jihadi- } \\
\text { inspired extremists, } \\
\text { one unknown } \\
\end{array}$ & $\begin{array}{l}\text { 16-year-old boy stabbed to death in } \\
\text { Hamburg and a truck attack at a Berlin } \\
\text { Christmas market. }\end{array}$ \\
\hline Ireland & 8 & no & 1 & 1 & $12 / 7 / 2016$ & $12 / 7 / 2016$ & $\begin{array}{c}\text { Dissident Irish } \\
\text { Republicans }\end{array}$ & $\begin{array}{l}\text { Rival dissident Irish Republican Aidan } \\
\text { O’Driscoll murdered. }\end{array}$ \\
\hline Netherlands & 2 & yes & 1 & 1 & $11 / 2 / 2004$ & $11 / 2 / 2004$ & $\begin{array}{l}\text { Hofstad Network } \\
\text { (Jihadist group) }\end{array}$ & Murder of filmmaker Theo van Gogh. \\
\hline Netherlands & 4 & yes & 1 & 7 & $5 / 1 / 2009$ & $5 / 1 / 2009$ & Unknown & $\begin{array}{l}\text { Car attack on festival for Dutch royal } \\
\text { family. }\end{array}$ \\
\hline Poland & 5 & no & 1 & 1 & $10 / 19 / 2010$ & $10 / 19 / 2010$ & $\begin{array}{l}\text { Anti-Government } \\
\text { extremists }\end{array}$ & Murder of politician Marek Rosiak. \\
\hline Spain & 1 & yes & 2 & 2 & $12 / 17 / 2002$ & $2 / 8 / 2003$ & $\begin{array}{l}\text { Basque Fatherland } \\
\text { and Freedom } \\
\text { (ETA) }\end{array}$ & $\begin{array}{l}\text { Police officer killed in a failed bombing } \\
\text { attack near Madrid and police officer } \\
\text { killed in Andoain. }\end{array}$ \\
\hline Spain & 3 & yes & 1 & 2 & $12 / 30 / 2006$ & $12 / 30 / 2006$ & $\begin{array}{l}\text { Basque Fatherland } \\
\text { and Freedom } \\
\text { (ETA) }\end{array}$ & $\begin{array}{l}\text { Bombing at Madrid airport in which } 12 \\
\text { were wounded. }\end{array}$ \\
\hline Spain & 4 & no & 2 & 2 & 9/22/2008 & $12 / 3 / 2008$ & $\begin{array}{l}\text { Basque Fatherland } \\
\text { and Freedom } \\
\text { (ETA) }\end{array}$ & $\begin{array}{l}\text { Car bombing in Santoña and murder of } \\
\text { businessman Ignacio Uría Mendizábal. }\end{array}$ \\
\hline
\end{tabular}




\begin{tabular}{|c|c|c|c|c|c|c|c|c|}
\hline Sweden & 5 & yes & 1 & 1 & $12 / 11 / 2010$ & $12 / 11 / 2010$ & Iraqi extremists & $\begin{array}{l}\text { Suicide bomber in Stockholm in which } \\
\text { only the bomber was killed. Two } \\
\text { bystanders were wounded. }\end{array}$ \\
\hline UK & 6 & yes & 2 & 2 & $10 / 25 / 2012$ & $11 / 1 / 2012$ & $\begin{array}{c}\text { The New Irish } \\
\text { Republican Army }\end{array}$ & $\begin{array}{l}\text { Murder of a drug dealer and murder of a } \\
\text { police officer, both in Northern Ireland. }\end{array}$ \\
\hline UK & 8 & yes & 1 & 1 & $10 / 20 / 2016$ & $10 / 20 / 2016$ & $\begin{array}{c}\text { The New Irish } \\
\text { Republican Army }\end{array}$ & $\begin{array}{l}\text { Murder of a suspected drug dealer in } \\
\text { Northern Ireland. }\end{array}$ \\
\hline UK & 9 & yes & 1 & 1 & $12 / 4 / 2018$ & $12 / 4 / 2018$ & $\begin{array}{l}\text { Irish National } \\
\text { Liberation Army } \\
\text { (INLA) }\end{array}$ & Civilian murdered in Northern Ireland. \\
\hline
\end{tabular}




\section{Table A3. Independent Variable Descriptive Statistics}

\begin{tabular}{lcc} 
& $\begin{array}{c}\text { Mean } \\
\text { (SD) }\end{array}$ & Description \\
\hline Age & 49.91 & \\
& $(18.77)$ & \\
Male & 0.46 & \\
& $(.50)$ & \\
Years Education & 12.74 & \\
& $(4.34)$ & \\
Minority & 0.05 & $=1$ if affirmative answer to "Do you belong to a minority \\
& $(0.22)$ & ethnic group in [country]?", = 0 otherwise \\
Income Coping & 0.83 & $=1$ if respondent indicates "Living comfortably on present \\
& $(0.37)$ & income” or “Coping on present income”, = 0 otherwise \\
N & 11,280 & \\
\hline
\end{tabular}

Notes: Survey-level means with standard deviations in parentheses. Includes any observations from our preferred 4-week bandwidth specification results from Table 4. Based on individual-level data from the European Social Surveys (ESS), 20022019. 
Table A4. Post-Attack Attitudes in the Region of the Attack, Two-Week Bandwidth

\begin{tabular}{|c|c|c|c|c|c|c|}
\hline & $\begin{array}{l}\text { Immigrants } \\
\text { make country } \\
\text { better }\end{array}$ & $\begin{array}{c}\text { Fewer } \\
\text { immigrants of } \\
\text { different } \\
\text { race/ethnicity }\end{array}$ & $\begin{array}{c}\text { Fewer } \\
\text { immigrants from } \\
\text { poorer countries }\end{array}$ & $\begin{array}{c}\text { Trust in } \\
\text { country's } \\
\text { parliament }\end{array}$ & $\begin{array}{c}\text { Satisfied with } \\
\text { national } \\
\text { government }\end{array}$ & $\begin{array}{c}\text { Trust in } \\
\text { European } \\
\text { Parliament }\end{array}$ \\
\hline Post attack & $\begin{array}{c}-.016 \\
(.071)\end{array}$ & $\begin{array}{c}.051 \\
(.031)\end{array}$ & $\begin{array}{c}.023 \\
(.023)\end{array}$ & $\begin{array}{c}.001 \\
(.064)\end{array}$ & $\begin{array}{l}-.077 \\
(.088)\end{array}$ & $\begin{array}{l}-.059 \\
(.081)\end{array}$ \\
\hline Post attack * Region & $\begin{array}{l}.338^{* *} \\
(.148)\end{array}$ & $\begin{array}{c}.052 \\
(.043)\end{array}$ & $\begin{array}{l}.086^{*} \\
(.041)\end{array}$ & $\begin{array}{c}.085 \\
(.070)\end{array}$ & $\begin{array}{c}.154 \\
(.180)\end{array}$ & $\begin{array}{c}.197 \\
(.141)\end{array}$ \\
\hline $\begin{array}{l}\mathrm{N} \\
\text { Mean of dep. var. }\end{array}$ & $\begin{array}{l}5890 \\
5.267\end{array}$ & $\begin{array}{l}5928 \\
2.323\end{array}$ & $\begin{array}{l}5940 \\
2.376\end{array}$ & $\begin{array}{l}5980 \\
4.263\end{array}$ & $\begin{array}{l}5963 \\
3.972\end{array}$ & $\begin{array}{l}5643 \\
4.178\end{array}$ \\
\hline $\begin{array}{l}\text { Country-by-round fixed effects } \\
\text { Individual controls }\end{array}$ & $\begin{array}{l}\text { yes } \\
\text { yes }\end{array}$ & $\begin{array}{l}\text { yes } \\
\text { yes }\end{array}$ & $\begin{array}{l}\text { yes } \\
\text { yes }\end{array}$ & $\begin{array}{l}\text { yes } \\
\text { yes }\end{array}$ & $\begin{array}{l}\text { yes } \\
\text { yes }\end{array}$ & $\begin{array}{l}\text { yes } \\
\text { yes }\end{array}$ \\
\hline
\end{tabular}

*Statistically significant at $10 \%$ level; ** at $5 \%$ level; *** at $1 \%$ level.

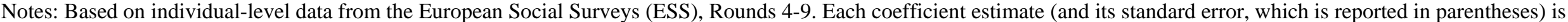

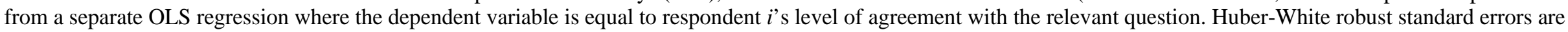

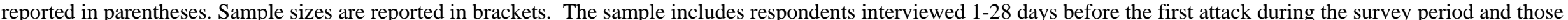

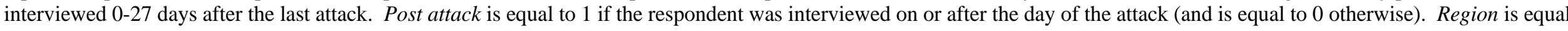

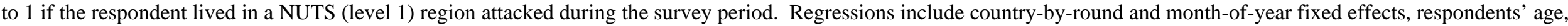
gender, years education, an indicator for living in an urban area, an indicator for minority status, and an indicator for respondent coping at current income level. 
Table A5. Individual Country-Round Results: Spain, Two-Week Bandwidth

\begin{tabular}{|c|c|c|c|c|c|c|}
\hline & $\begin{array}{c}\text { Immigrants make } \\
\text { country better }\end{array}$ & $\begin{array}{c}\text { Fewer immigrants } \\
\text { of different } \\
\text { racelethnicity }\end{array}$ & $\begin{array}{c}\text { Fewer immigrants } \\
\text { from poorer } \\
\text { countries }\end{array}$ & $\begin{array}{c}\text { Trust in country's } \\
\text { parliament }\end{array}$ & $\begin{array}{l}\text { Satisfied with } \\
\text { national } \\
\text { government }\end{array}$ & $\begin{array}{c}\text { Trust in European } \\
\text { Parliament }\end{array}$ \\
\hline \multicolumn{7}{|c|}{ Panel A: Spain Round 1} \\
\hline \multirow[t]{3}{*}{ Post attack } & 0.123 & 0.061 & -0.031 & $-.733^{* *}$ & $-.539 *$ & -0.228 \\
\hline & -0.229 & -0.099 & -0.097 & -0.301 & -0.277 & -0.283 \\
\hline & [628] & {$[612]$} & {$[617]$} & [609] & {$[631]$} & {$[566]$} \\
\hline Mean of dep. var. & 4.776 & 2.417 & 2.448 & 4.738 & 4.036 & 4.713 \\
\hline \multicolumn{7}{|c|}{ Panel B: Spain Round 3} \\
\hline \multirow[t]{3}{*}{ Post attack } & -0.437 & 0.011 & -0.003 & -0.085 & -0.138 & 0.174 \\
\hline & -0.278 & -0.11 & -0.111 & -0.297 & -0.308 & -0.279 \\
\hline & [292] & [288] & {$[286]$} & {$[287]$} & {$[286]$} & {$[261]$} \\
\hline Mean of dep. var. & 4.7924 .784 & 2.489 & 2.458 & 5.176 & 4.851 & 5.342 \\
\hline
\end{tabular}

*Statistically significant at $10 \%$ level; ** at $5 \%$ level; *** at $1 \%$ level.

Notes: Based on individual-level data from the European Social Surveys (ESS). Each coefficient estimate is from a separate OLS regression where the dependent variable is equal to respondent $i$ 's level of agreement with the relevant question. Huber-White robust standard errors are reported in parentheses. The sample includes respondents interviewed 1-14 days before the first attack during the survey period and those interviewed 0-13 days after the last attack. Post attack is equal to 1 if the respondent was interviewed on or after the day of the attack (and is equal to 0 otherwise). Regressions include respondents' age, gender, years education, an indicator for living in an urban area, an indicator for minority status, and an indicator for respondent coping at current income level. 
Table A6. Individual Country-Round Results: France, Two-Week Bandwidth

\begin{tabular}{|c|c|c|c|c|c|c|}
\hline & $\begin{array}{c}\text { Immigrants make } \\
\text { country better }\end{array}$ & $\begin{array}{c}\text { Fewer immigrants } \\
\text { of different } \\
\text { race/ethnicity }\end{array}$ & $\begin{array}{c}\text { Fewer immigrants } \\
\text { from poorer } \\
\text { countries }\end{array}$ & $\begin{array}{c}\text { Trust in country's } \\
\text { parliament }\end{array}$ & $\begin{array}{c}\text { Satisfied with } \\
\text { national } \\
\text { government }\end{array}$ & $\begin{array}{c}\text { Trust in European } \\
\text { Parliament }\end{array}$ \\
\hline \multicolumn{7}{|c|}{ Panel A: France Round 7} \\
\hline \multirow[t]{3}{*}{ Post attack } & 0.082 & -0.012 & 0.026 & $.574 *$ & $.863 * * *$ & 0.349 \\
\hline & -0.273 & -0.086 & -0.093 & -0.308 & -0.273 & -0.314 \\
\hline & {$[541]$} & {$[536]$} & {$[542]$} & {$[544]$} & {$[544]$} & {$[530]$} \\
\hline Mean of dep. var. & 5.057 & 2.302 & 2.462 & 4.286 & 3.221 & 4.249 \\
\hline \multicolumn{7}{|c|}{ Panel B: France Round 8} \\
\hline \multirow[t]{3}{*}{ Post attack } & 0.022 & 0.037 & -0.013 & 0.305 & 0.062 & 0.053 \\
\hline & -0.212 & -0.078 & -0.077 & -0.236 & -0.226 & -0.221 \\
\hline & {$[709]$} & {$[710]$} & [709] & {$[712]$} & {$[710]$} & {$[701]$} \\
\hline Mean of dep. var. & 4.933 & 2.309 & 2.345 & 4.22 & 3.198 & 3.912 \\
\hline \multicolumn{7}{|c|}{ Panel c: France Round 9} \\
\hline \multirow[t]{3}{*}{ Post attack } & -0.172 & 0.114 & 0.146 & 0.146 & 0.178 & 0.246 \\
\hline & -0.232 & -0.089 & -0.099 & -0.099 & -0.272 & -0.272 \\
\hline & {$[443]$} & {$[437]$} & {$[442]$} & {$[445]$} & [449] & [436] \\
\hline Mean of dep. var. & 5.203 & 2.214 & 2.272 & 3.898 & 3.427 & 4.036 \\
\hline
\end{tabular}

*Statistically significant at $10 \%$ level; ** at $5 \%$ level; *** at $1 \%$ level.

Notes: Based on individual-level data from the European Social Surveys (ESS). Each coefficient estimate is from a separate OLS regression where the dependent variable is equal to respondent $i$ 's level of agreement with the relevant question. Huber-White robust standard errors are reported in parentheses. The sample includes respondents interviewed 1-14 days before the first attack during the survey period and those interviewed 0-13 days after the last attack. Post attack is equal to 1 if the respondent was interviewed on or after the day of the attack (and is equal to 0 otherwise). Regressions include respondents' age, gender, years education, an indicator for living in an urban area, an indicator for minority status, and an indicator for respondent coping at current income level. 
Table A7. Individual Country-Round Results: United Kingdom, Two-Week Bandwidth

\begin{tabular}{|c|c|c|c|c|c|c|}
\hline & $\begin{array}{l}\text { Immigrants make } \\
\text { country better }\end{array}$ & $\begin{array}{c}\text { Fewer immigrants } \\
\text { of different } \\
\text { race/ethnicity }\end{array}$ & $\begin{array}{c}\text { Fewer immigrants } \\
\text { from poorer } \\
\text { countries }\end{array}$ & $\begin{array}{c}\text { Trust in country's } \\
\text { parliament }\end{array}$ & $\begin{array}{l}\text { Satisfied with } \\
\text { national } \\
\text { government }\end{array}$ & $\begin{array}{c}\text { Trust in European } \\
\text { Parliament }\end{array}$ \\
\hline \multicolumn{7}{|c|}{ Panel A: UK Round 6} \\
\hline \multirow[t]{3}{*}{ Post attack } & 0.034 & -0.036 & 0.045 & 0.217 & $.412 *$ & 0.015 \\
\hline & -0.221 & -0.08 & -0.086 & -0.241 & -0.239 & -0.224 \\
\hline & {$[501]$} & [499] & {$[498]$} & {$[502]$} & {$[503]$} & {$[432]$} \\
\hline Mean of dep. var. & 5.029 & 2.483 & 2.618 & 4.337 & 4.131 & 3.476 \\
\hline \multicolumn{7}{|c|}{ Panel B: UK Round 8} \\
\hline \multirow[t]{3}{*}{ Post attack } & -0.081 & 0.095 & 0 & -0.202 & -0.213 & -0.088 \\
\hline & -0.172 & -0.064 & -0.069 & -0.175 & -0.182 & -0.193 \\
\hline & {$[820]$} & {$[808]$} & [809] & {$[823]$} & {$[815]$} & {$[786]$} \\
\hline Mean of dep. var. & 5.606 & 2.195 & 2.296 & 4.598 & 4.595 & 3.669 \\
\hline \multicolumn{7}{|c|}{ Panel c: UK Round 9} \\
\hline \multirow[t]{3}{*}{ Post attack } & -0.305 & 0.154 & 0.183 & -0.153 & -0.261 & 0.01 \\
\hline & -0.481 & -0.173 & -0.176 & -0.477 & -0.552 & -0.566 \\
\hline & [109] & [109] & [109] & [109] & [109] & [108] \\
\hline Mean of dep. var. & 5.848 & 2.144 & 2.235 & 4.294 & 3.929 & 3.445 \\
\hline
\end{tabular}

*Statistically significant at $10 \%$ level; ** at $5 \%$ level; *** at $1 \%$ level.

Notes: Based on individual-level data from the European Social Surveys (ESS). Each coefficient estimate is from a separate OLS regression where the dependent variable is equal to respondent $i$ 's level of agreement with the relevant question. Huber-White robust standard errors are reported in parentheses. The sample includes respondents interviewed 1-14 days before the first attack during the survey period and those interviewed 0-13 days after the last attack. Post attack is equal to 1 if the respondent was interviewed on or after the day of the attack (and is equal to 0 otherwise). Regressions include respondents' age, gender, years education, an indicator for living in an urban area, an indicator for minority status, and an indicator for respondent coping at current income level. 
Table A8. Individual Country-Round Results: the Netherlands, Two-Week Bandwidth

\begin{tabular}{|c|c|c|c|c|c|c|}
\hline & $\begin{array}{c}\text { Immigrants make } \\
\text { country better }\end{array}$ & $\begin{array}{c}\text { Fewer immigrants } \\
\text { of different } \\
\text { race/ethnicity }\end{array}$ & $\begin{array}{c}\text { Fewer immigrants } \\
\text { from poorer } \\
\text { countries }\end{array}$ & $\begin{array}{c}\text { Trust in country's } \\
\text { parliament }\end{array}$ & $\begin{array}{c}\text { Satisfied with } \\
\text { national } \\
\text { government } \\
\end{array}$ & $\begin{array}{c}\text { Trust in Europear } \\
\text { Parliament }\end{array}$ \\
\hline \multicolumn{7}{|c|}{ Panel A: Netherlands Round 2} \\
\hline \multirow[t]{3}{*}{ Post attack } & $-.559 * *$ & -0.035 & -0.002 & 0.2 & 0.091 & 0.21 \\
\hline & -0.229 & -0.088 & -0.091 & -0.206 & -0.213 & -0.213 \\
\hline & {$[455]$} & {$[453]$} & {$[452]$} & {$[454]$} & {$[453]$} & [397] \\
\hline Mean of dep. var. & 4.965 & 2.494 & 2.602 & 4.782 & 4.529 & 4.958 \\
\hline \multicolumn{7}{|c|}{ Panel B: Netherlands Round 4} \\
\hline \multirow[t]{3}{*}{ Post attack } & $.621 *$ & $-.273^{*}$ & -0.236 & $.667 *$ & 0.151 & 0.336 \\
\hline & -0.344 & -0.163 & -0.166 & -0.338 & -0.361 & -0.444 \\
\hline & {$[135]$} & {$[133]$} & {$[133]$} & {$[136]$} & {$[136]$} & {$[127]$} \\
\hline Mean of dep. var. & 5.009 & 2.373 & 2.436 & 5.44 & 5.221 & 4.687 \\
\hline
\end{tabular}

*Statistically significant at $10 \%$ level; ** at $5 \%$ level; *** at $1 \%$ level.

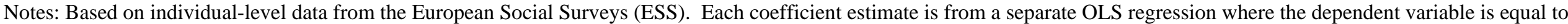

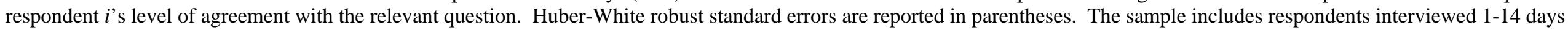

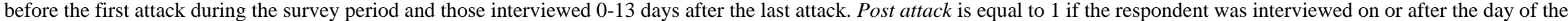

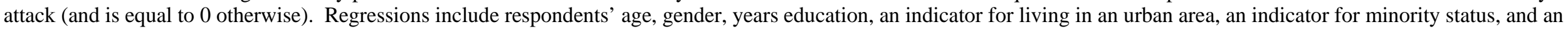
indicator for respondent coping at current income level. 
Table A9. Individual Country-Round Results: Germany and Sweden, Two-Week Bandwidth

\begin{tabular}{|c|c|c|c|c|c|c|}
\hline & $\begin{array}{c}\text { Immigrants make } \\
\text { country better }\end{array}$ & $\begin{array}{c}\text { Fewer immigrants } \\
\text { of different } \\
\text { race/ethnicity }\end{array}$ & $\begin{array}{c}\text { Fewer immigrants } \\
\text { from poorer } \\
\text { countries }\end{array}$ & $\begin{array}{c}\text { Trust in country's } \\
\text { parliament }\end{array}$ & $\begin{array}{c}\text { Satisfied with } \\
\text { national } \\
\text { government }\end{array}$ & $\begin{array}{c}\text { Trust in Europear } \\
\text { Parliament }\end{array}$ \\
\hline \multicolumn{7}{|c|}{ Panel A: Germany Round 8} \\
\hline \multirow[t]{3}{*}{ Post attack } & -0.019 & 0.005 & 0.025 & -0.256 & 0.052 & -0.29 \\
\hline & -0.251 & -0.087 & -0.095 & -0.283 & -0.25 & -0.255 \\
\hline & [350] & [348] & [349] & [345] & [346] & [340] \\
\hline Mean of dep. var. & 5.311 & 2.037 & 2.141 & 5.263 & 4.964 & 4.335 \\
\hline \multicolumn{7}{|c|}{ Panel B: Sweden Round 5} \\
\hline \multirow[t]{3}{*}{ Post attack } & $.857 * * *$ & -0.104 & -0.079 & $.484^{*}$ & -0.216 & 0.141 \\
\hline & -0.31 & -0.091 & -0.094 & -0.284 & -0.318 & -0.339 \\
\hline & [236] & [232] & [233] & [235] & {$[230]$} & {$[212]$} \\
\hline Mean of dep. var. & 6.827 & 1.715 & 1.747 & 6.482 & 6.11 & 4.993 \\
\hline
\end{tabular}

*Statistically significant at $10 \%$ level; ** at $5 \%$ level; *** at $1 \%$ level.

Notes: Based on individual-level data from the European Social Surveys (ESS). Each coefficient estimate is from a separate OLS regression where the dependent variable is equal to respondent $i$ 's level of agreement with the relevant question. Huber-White robust standard errors are reported in parentheses. The sample includes respondents interviewed 1-14 days before the first attack during the survey period and those interviewed 0-13 days after the last attack. Post attack is equal to 1 if the respondent was interviewed on or after the day of the attack (and is equal to 0 otherwise). Regressions include respondents' age, gender, years education, an indicator for living in an urban area, an indicator for minority status, and an indicator for respondent coping at current income level. 
Figure A1. Pre- and Post-Attack Interview Counts for County-Round Pairs (4-Week Bandwidth Sample)
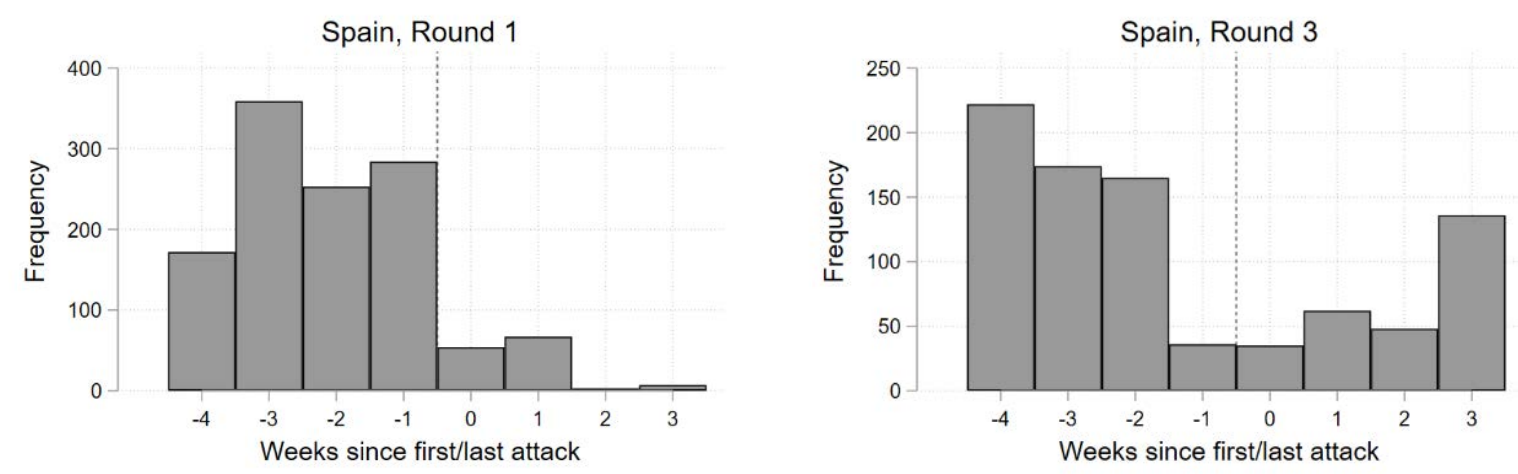

France, Round 7
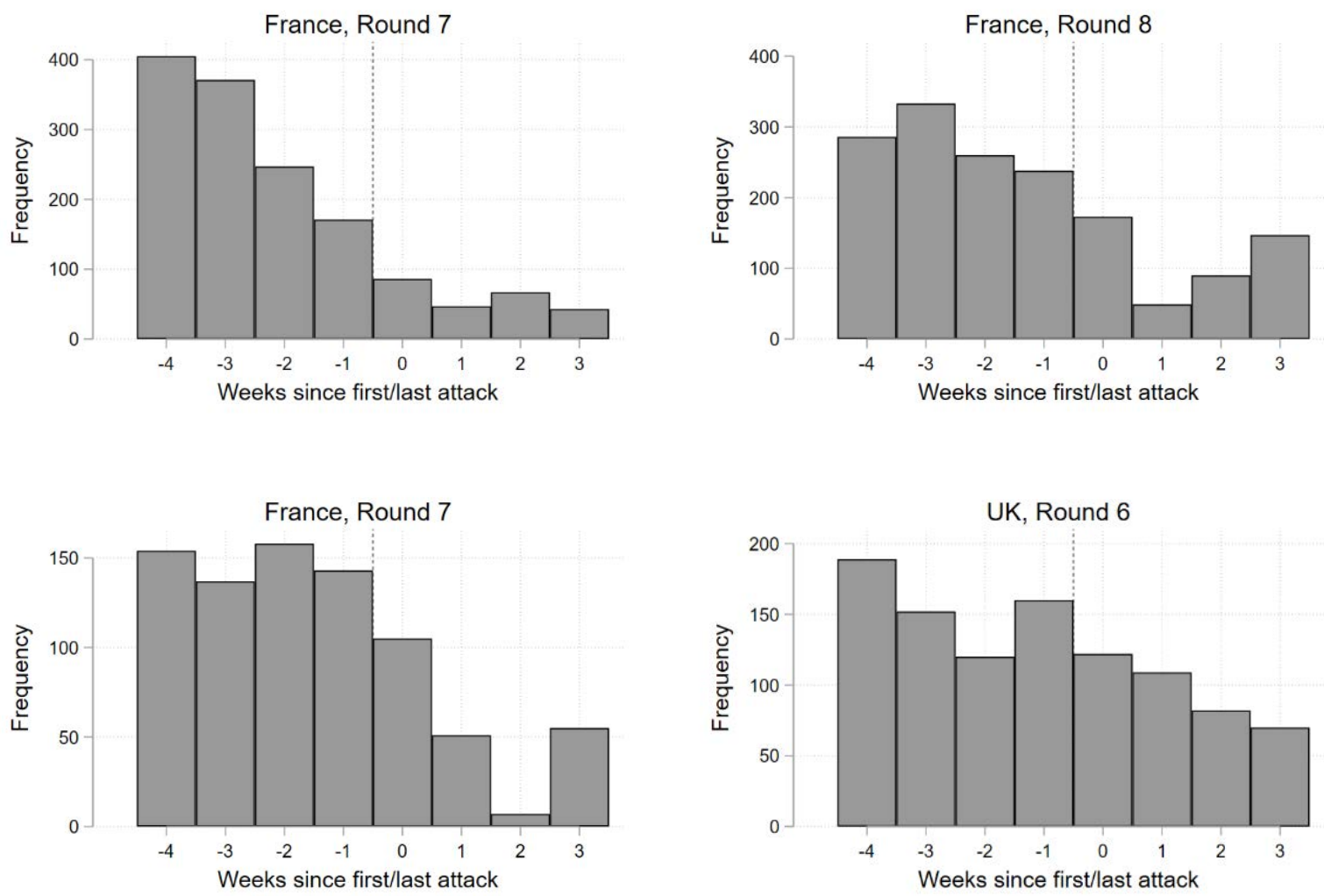

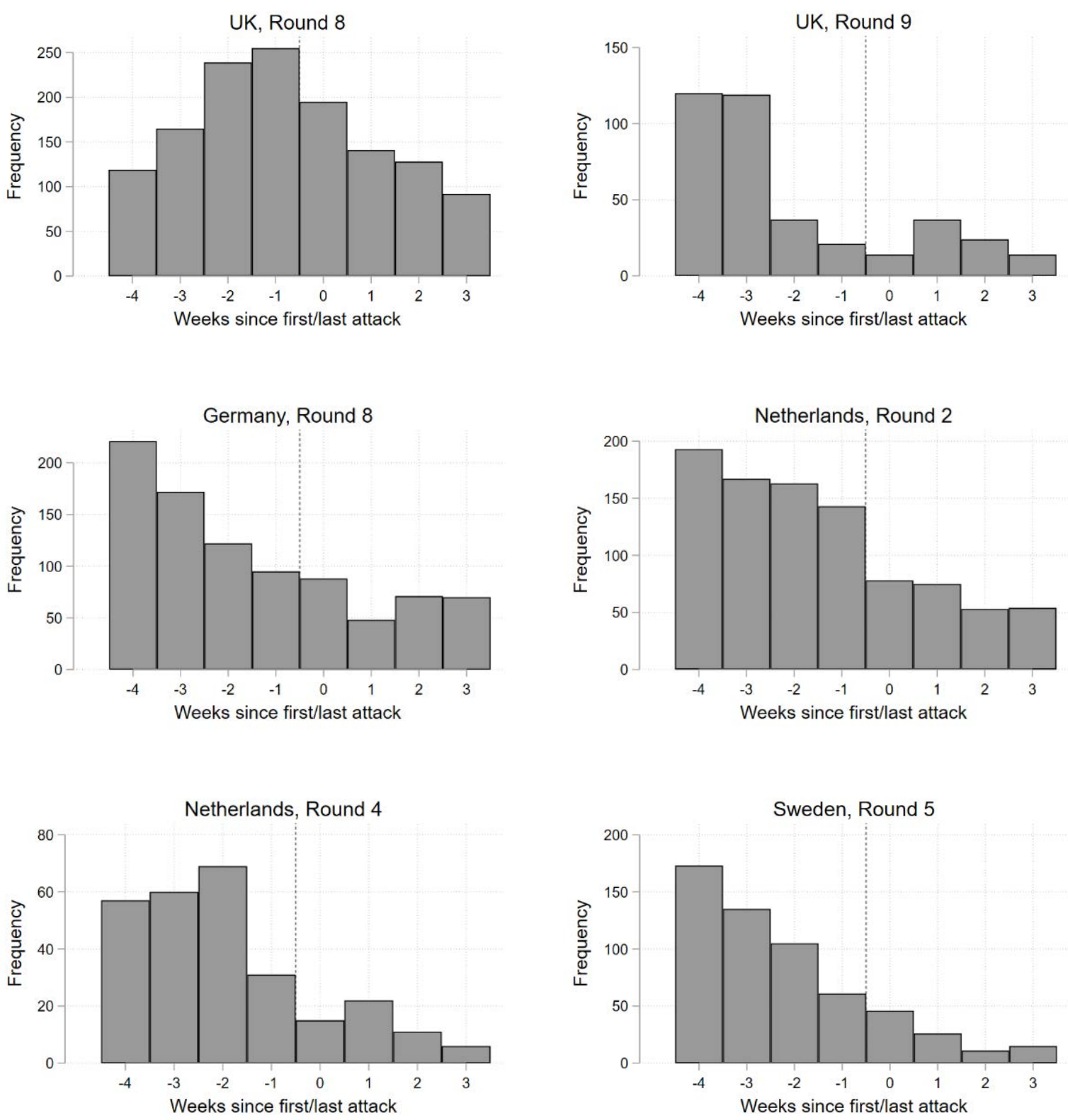

Notes: Figures show interview counts by weeks since the first/last attack. The zero-week indicator is for interviews that were conducted 0-6 days after the last attack. The one-week indicator is for interviews conducted 7-13 days after the last attack, and so forth. Interview counts are shown for the 12 country-round pairs comprising our 4-week bandwidth sample. 


\section{Figure A2. Pre- and Post-Attack Interview Counts for County-Round Pairs (Two-Week Bandwidth Sample)}
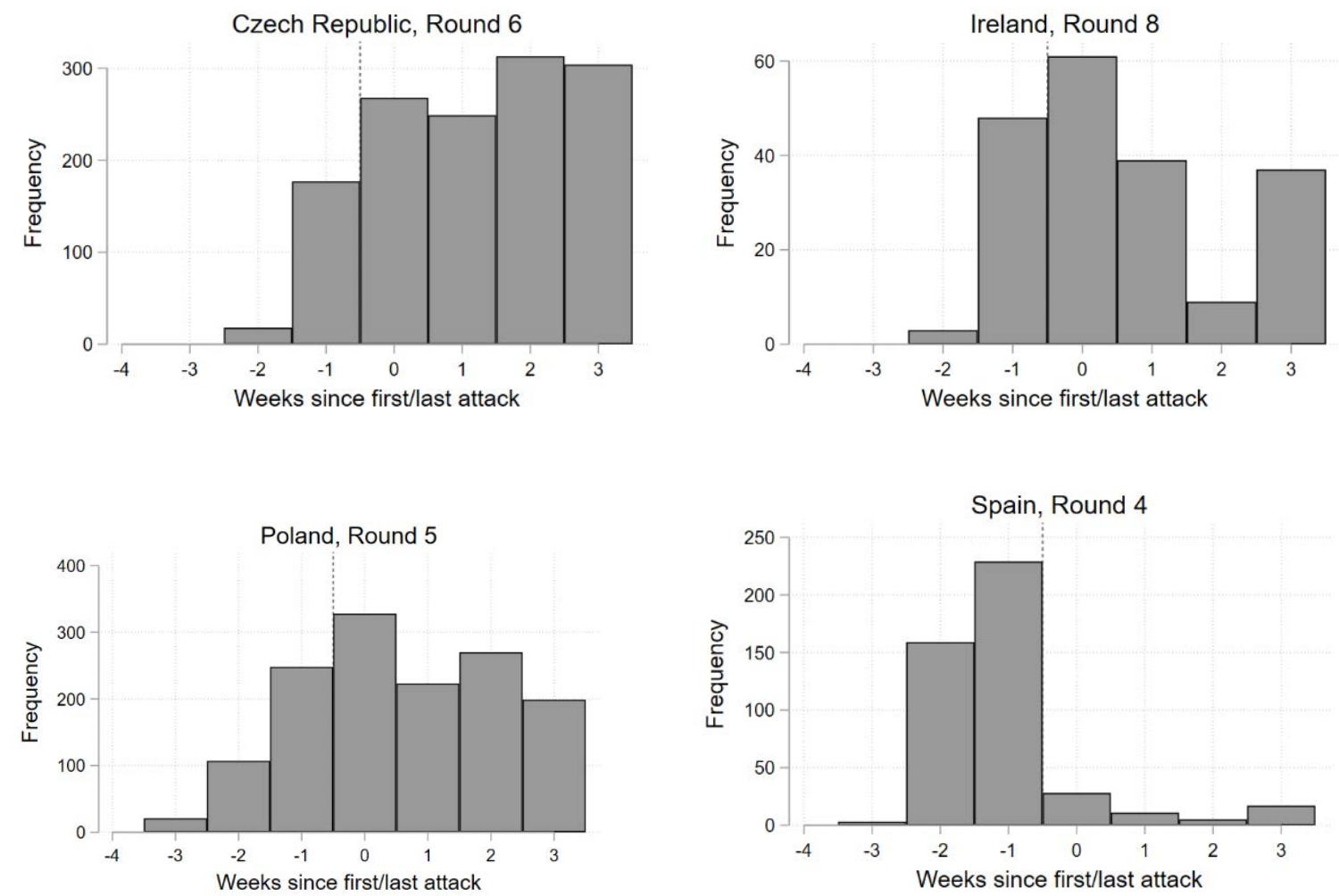

Notes: Figures show interview counts by weeks since the first/last attack. The zero-week indicator is for interviews that were conducted 0-6 days after the last attack. The one-week indicator is for interviews conducted 7-13 days after the last attack, and so forth. Interview counts are shown for the 4 country-round pairs that are included in the two-week bandwidth sample but not the 4-week bandwidth sample. 


\section{Figure A3. Event Study Estimates: Fatal Terror Attacks and "Immigrants Make Country Better Place to Live” (8-Week Bandwidth)}

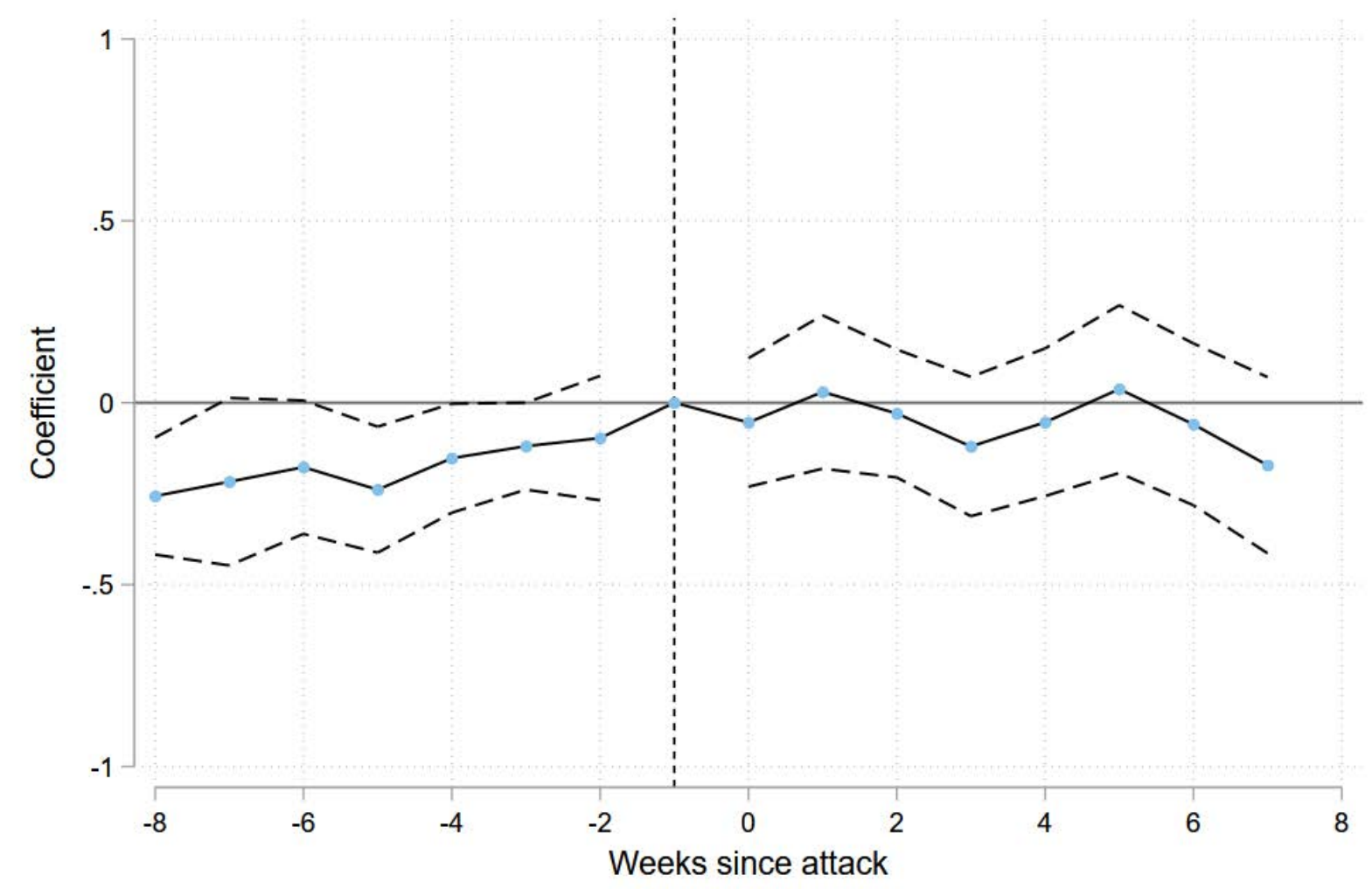

Notes: Based on individual-level data from the European Social Surveys (ESS). Figure plots the coefficient estimates for the weeks-since-attack indicators as described in the text, along with 90\% confidence intervals. The sample includes respondents interviewed 1-56 days before the first attack during the survey period and those interviewed 0-55 days after the last attack. Regressions include country-by-round and month-of-year fixed effects, respondents' age, gender, years education, an indicator for living in an urban area, an indicator for minority status, and an indicator for respondent coping at current income level. 


\section{Figure A4. Event Study Estimates: Fatal Terror Attacks and "Allow Fewer Immigrants of Different Race/Ethnicity” (8-Week Bandwidth)}

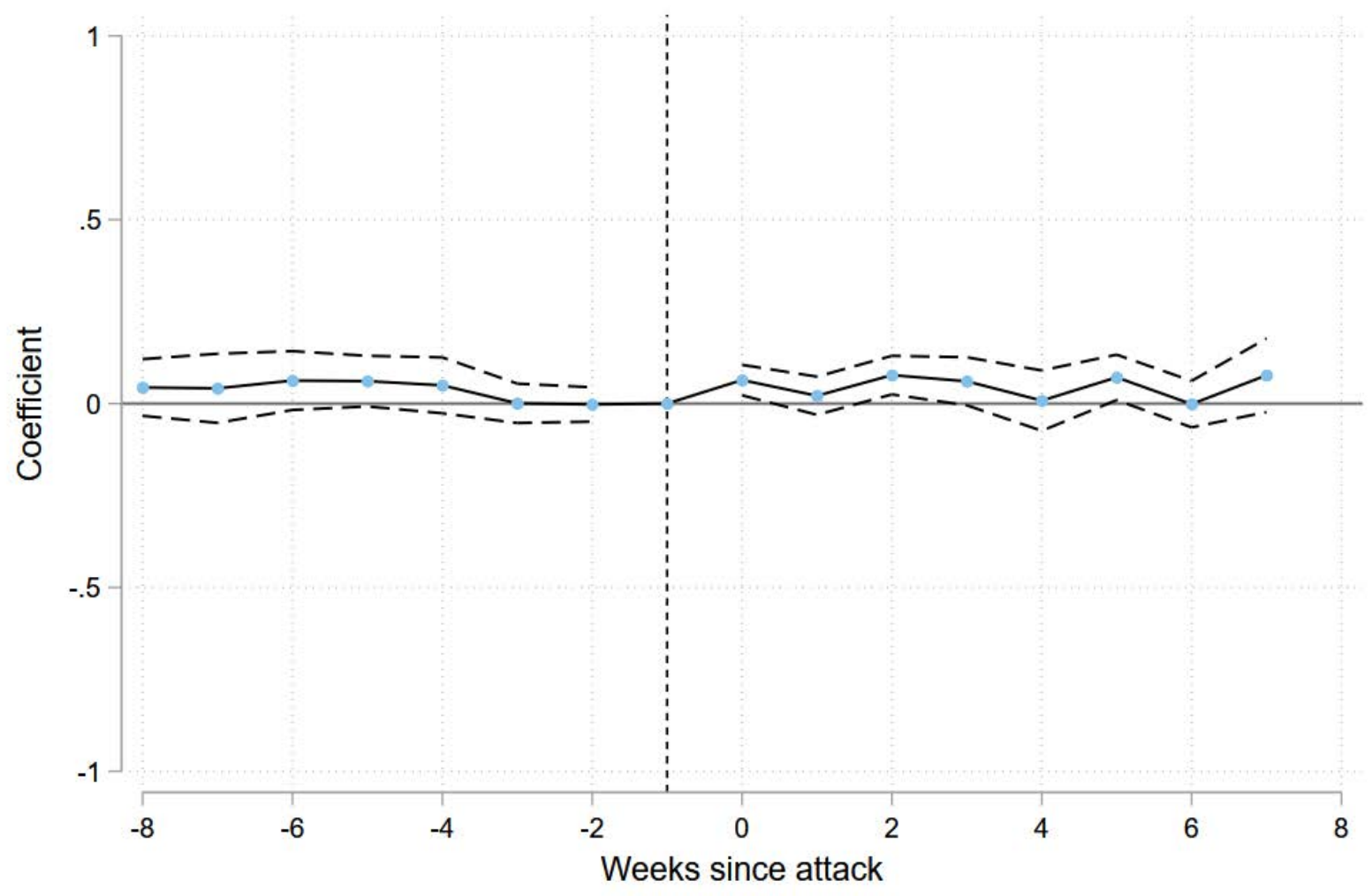

Notes: Based on individual-level data from the European Social Surveys (ESS). Figure plots the coefficient estimates for the weeks-since-attack indicators as described in the text, along with $90 \%$ confidence intervals. The sample includes respondents interviewed 1-56 days before the first attack during the survey period and those interviewed 0-55 days after the last attack. Regressions include country-by-round and month-of-year fixed effects, respondents' age, gender, years education, an indicator for living in an urban area, an indicator for minority status, and an indicator for respondent coping at current income level. 


\section{Figure A5. Event Study Estimates: Fatal Terror Attacks and "Allow Fewer Immigrants from Poorer Countries” (8-Week Bandwidth)}

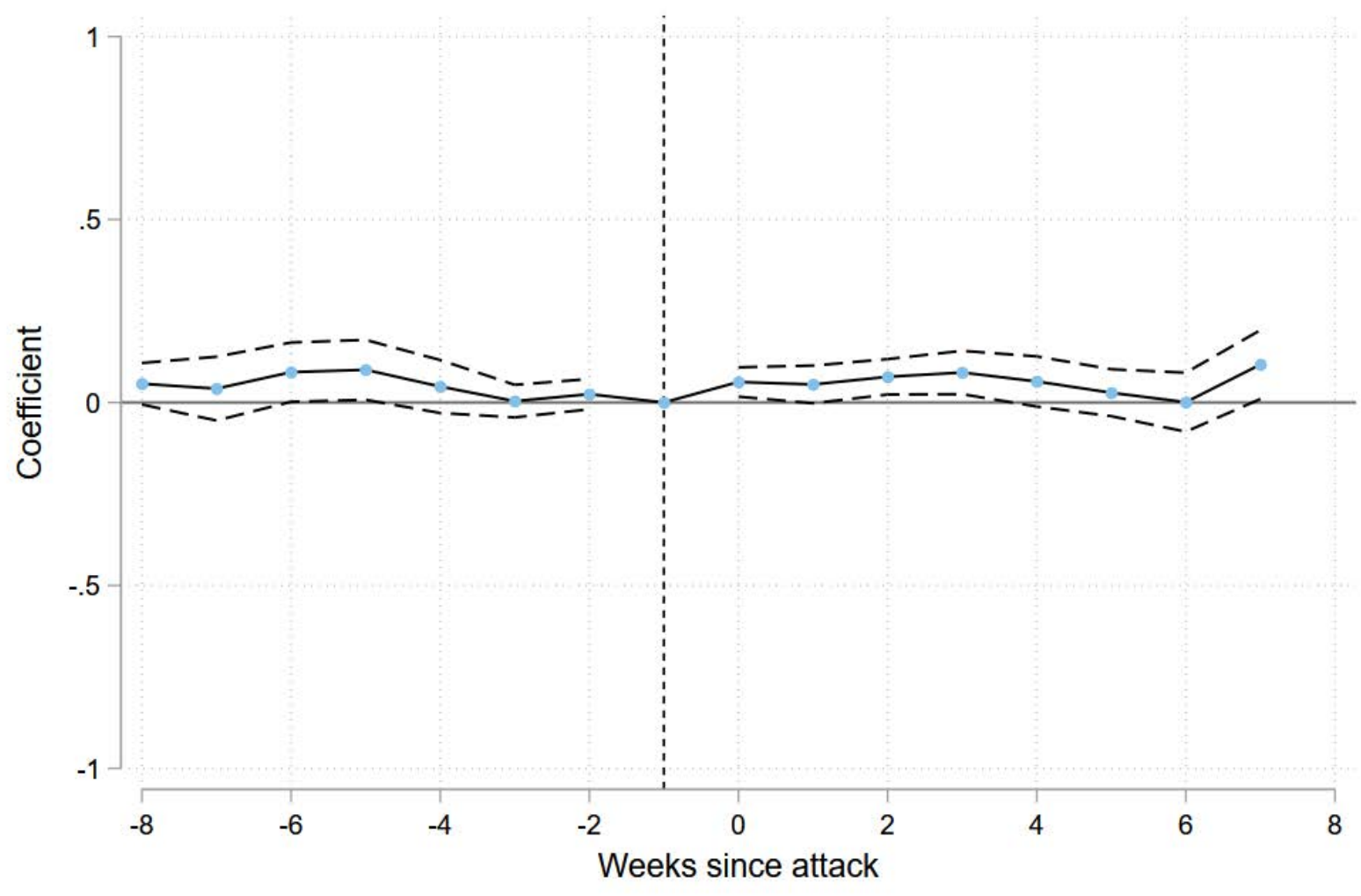

Notes: Based on individual-level data from the European Social Surveys (ESS). Figure plots the coefficient estimates for the weeks-since-attack indicators as described in the text, along with $90 \%$ confidence intervals. The sample includes respondents interviewed 1-56 days before the first attack during the survey period and those interviewed 0-55 days after the last attack. Regressions include country-by-round and month-of-year fixed effects, respondents' age, gender, years education, an indicator for living in an urban area, an indicator for minority status, and an indicator for respondent coping at current income level. 


\section{Figure A6. Event Study Estimates: Fatal Terror Attacks and “Trust in Country's Parliament” (8-Week Bandwidth)}

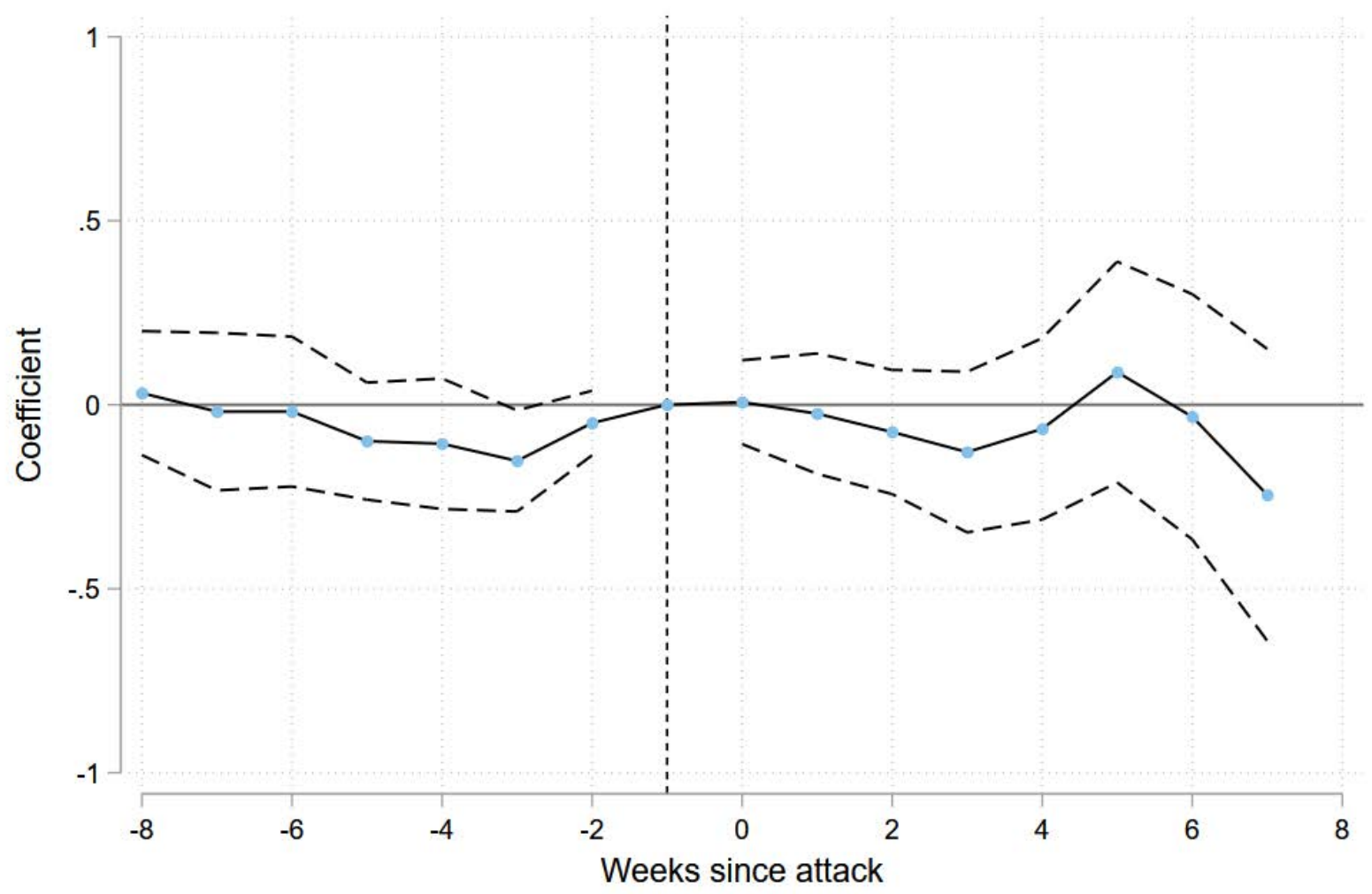

Notes: Based on individual-level data from the European Social Surveys (ESS). Figure plots the coefficient estimates for the weeks-since-attack indicators as described in the text, along with $90 \%$ confidence intervals. The sample includes respondents interviewed 1-56 days before the first attack during the survey period and those interviewed 0-55 days after the last attack. Regressions include country-by-round and month-of-year fixed effects, respondents' age, gender, years education, an indicator for living in an urban area, an indicator for minority status, and an indicator for respondent coping at current income level. 


\section{Figure A7. Event Study Estimates: Fatal Terror Attacks and "How Satisfied with National Government” (8-Week Bandwidth)}

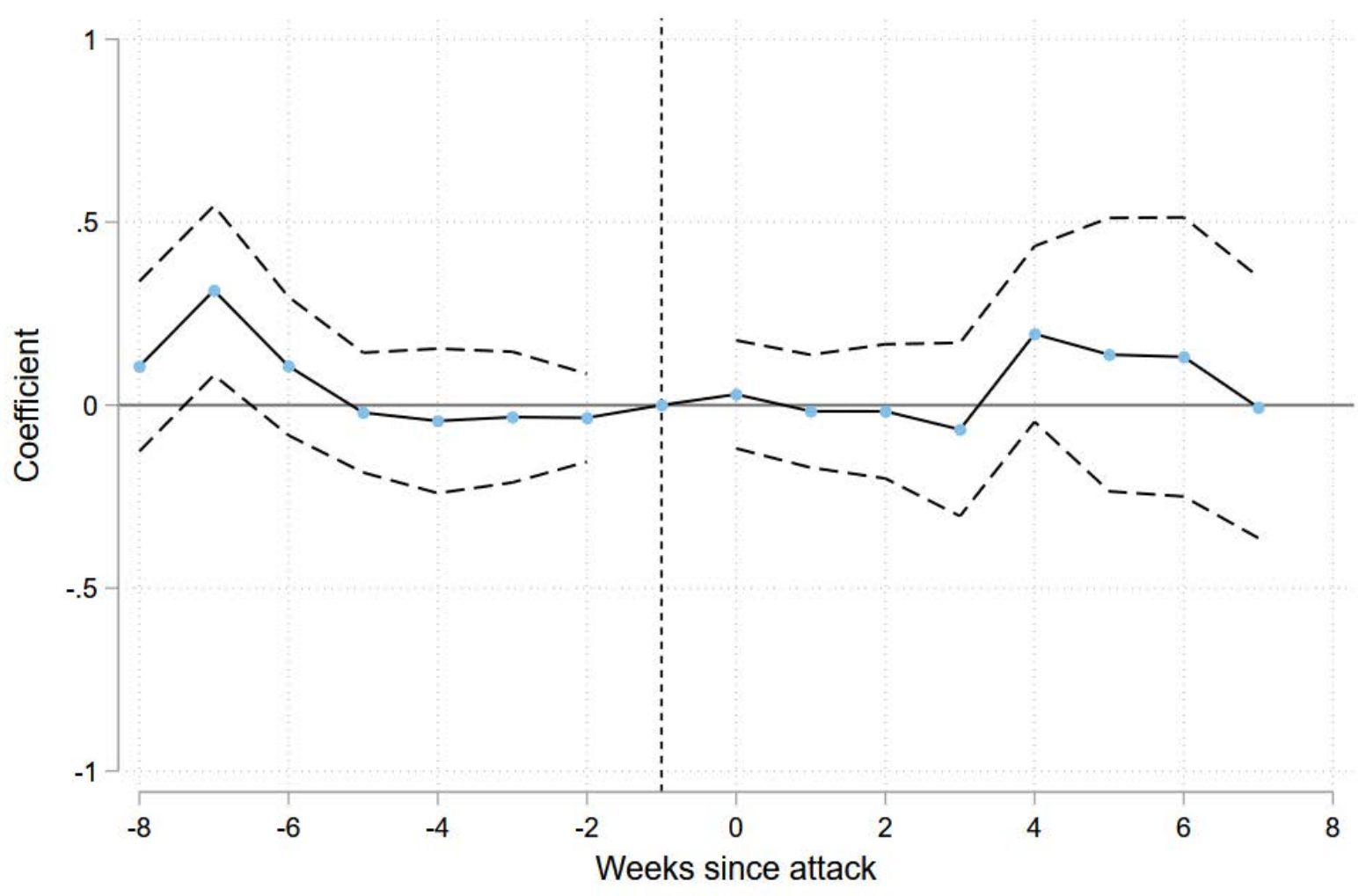

Notes: Based on individual-level data from the European Social Surveys (ESS). Figure plots the coefficient estimates for the weeks-since-attack indicators as described in the text, along with $90 \%$ confidence intervals. The sample includes respondents interviewed 1-56 days before the first attack during the survey period and those interviewed 0-55 days after the last attack. Regressions include country-by-round and month-of-year fixed effects, respondents' age, gender, years education, an indicator for living in an urban area, an indicator for minority status, and an indicator for respondent coping at current income level. 


\section{Figure A8. Event Study Estimates: Fatal Terror Attacks and “Trust in European Parliament” (8-Week Bandwidth)}

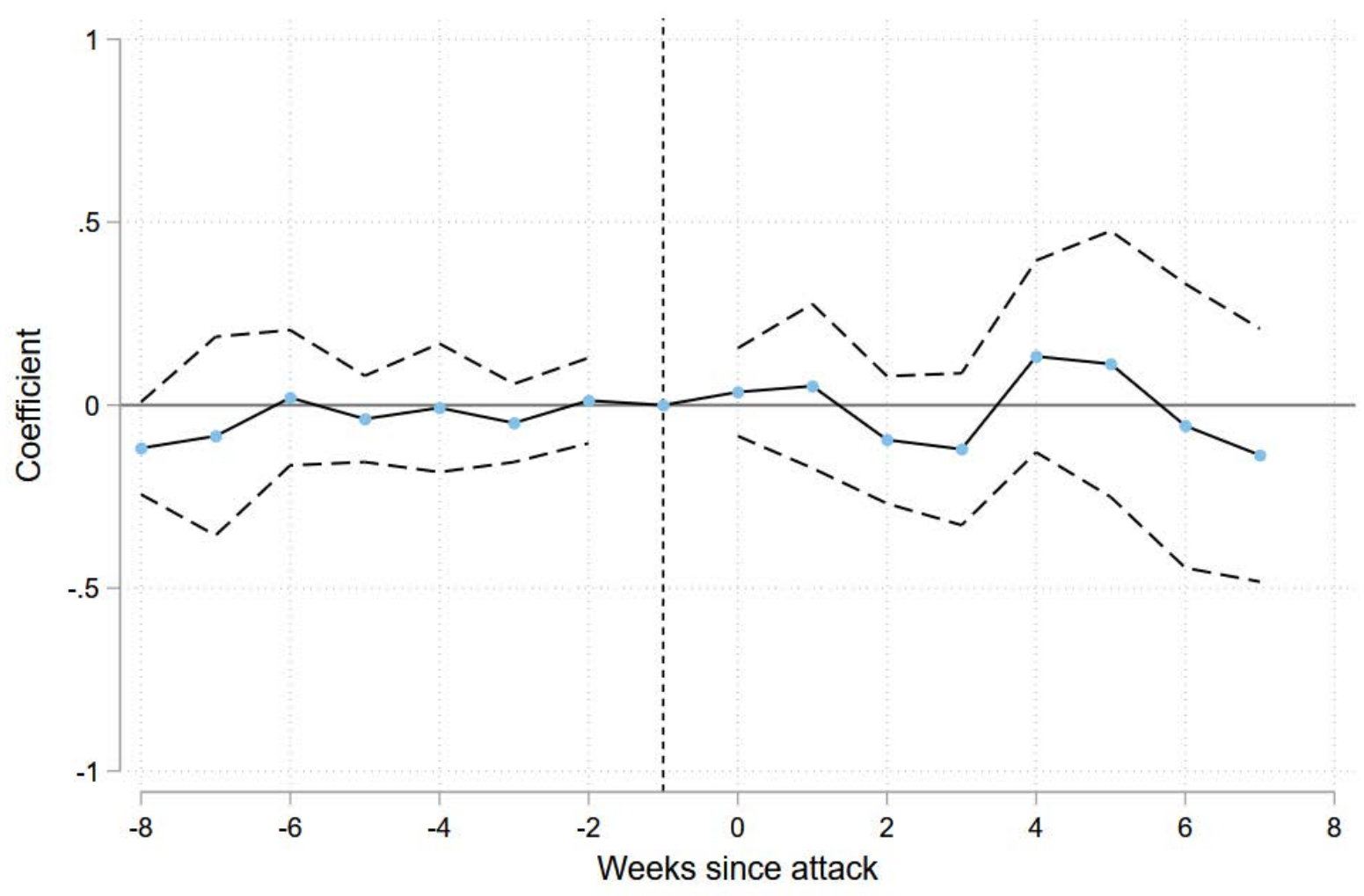

Notes: Based on individual-level data from the European Social Surveys (ESS). Figure plots the coefficient estimates for the weeks-since-attack indicators as described in the text, along with $90 \%$ confidence intervals. The sample includes respondents interviewed 1-56 days before the first attack during the survey period and those interviewed 0-55 days after the last attack. Regressions include country-by-round and month-of-year fixed effects, respondents' age, gender, years education, an indicator for living in an urban area, an indicator for minority status, and an indicator for respondent coping at current income level. 


\section{Figure A9. Event Study Estimates for Affected Region: Fatal Terror Attacks and “Trust in Country's Parliament"}

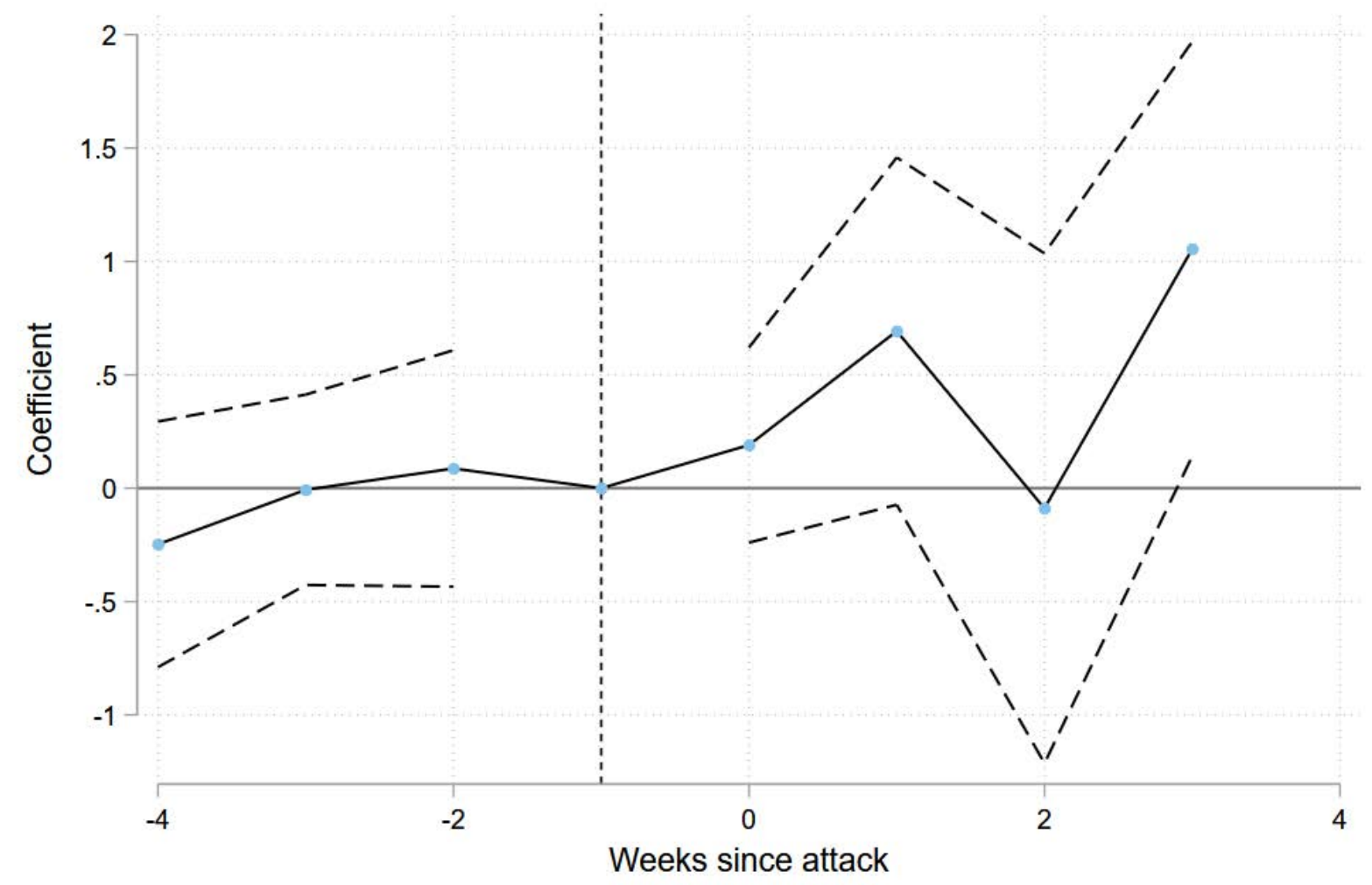

Notes: Based on individual-level data from the European Social Surveys (ESS). Figure plots coefficient estimates from equation (3) for weeks-since-attack indicators as described in the text, along with $90 \%$ confidence intervals. The sample includes respondents interviewed 1-28 days before the first attack during the survey period and respondents interviewed 0-27 days after the last attack. Regressions include region-by-round and month-of-year fixed effects, and control for respondents' age, gender, years education, an indicator for living in an urban area, an indicator for minority status, and an indicator for respondent coping at current income level. 


\section{Figure A10. Event Study Estimates for Affected Region: Fatal Terror Attacks and "How Satisfied with National Government"}

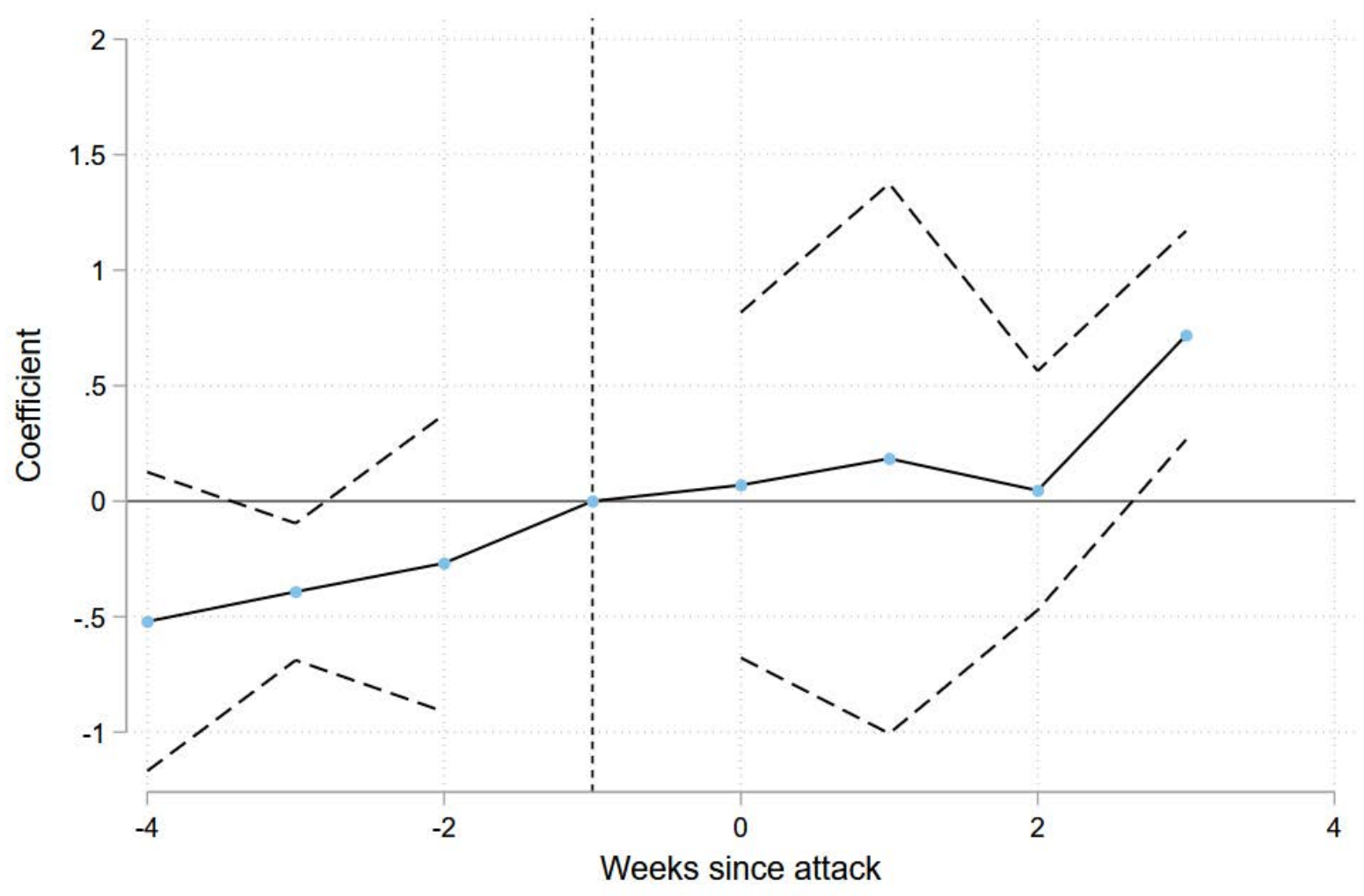

Notes: Based on individual-level data from the European Social Surveys (ESS). Figure plots coefficient estimates from equation (3) for weeks-since-attack indicators as described in the text, along with $90 \%$ confidence intervals. The sample includes respondents interviewed 1-28 days before the first attack during the survey period and respondents interviewed 0-27 days after the last attack. Regressions include region-by-round and month-of-year fixed effects, and control for respondents' age, gender, years education, an indicator for living in an urban area, an indicator for minority status, and an indicator for respondent coping at current income level. 


\section{APPENDIX B. TEXT OF EES QUESTIONS AS THEY APPEAR IN SURVEY}

B43 CARD 18 Is [country] made a worse or a better place to live by people coming to live here from other countries? Please use this card.

$\begin{array}{lrr}\text { Worse } & \text { Better } & \text { (Refusal) } \\ \text { place to } & \text { place to } & \text { know't } \\ \text { live } & \text { live } & \text { know) }\end{array}$

$\begin{array}{lllllllllllll}00 & 01 & 02 & 03 & 04 & 05 & 06 & 07 & 08 & 09 & 10 & 77 & 88\end{array}$

Now some questions about people from other countries coming to live in [country].

B38 CARD 15 Now, using this card, to what extent do you think [country] should ${ }^{29}$ allow people of the same race or ethnic group as most [country]'s people to come and live here ${ }^{30}$ ?

$\begin{array}{rr}\text { Allow many to come and live here } & 1 \\ \text { Allow some } & 2 \\ \text { Allow a few } & 3 \\ \text { Allow none } & 4 \\ \text { (Refusal) } & 7 \\ \text { (Don't know) } & 8\end{array}$


B39 STILL CARD 15 How about people of a different race or ethnic group from most [country] people? Still use this card.

\begin{tabular}{|c|c|}
\hline Allow many to come and live here & \\
\hline Allow some & \\
\hline Allow a few & \\
\hline Allow none & \\
\hline $\begin{array}{r}\text { (Refusal) } \\
\text { (Don't know) }\end{array}$ & \\
\hline
\end{tabular}

B40 STILL CARD 15 How about people from the poorer countries outside Europe? Use the same card.

$\begin{array}{rr}\text { Allow many to come and live here } & 1 \\ \text { Allow some } & 2 \\ \text { Allow a few } & 3 \\ \text { Allow none } & 4 \\ & \\ \text { (Refusal) } & 7 \\ \text { (Don't know) } & 8\end{array}$


CARD 9 Using this card, please tell me on a score of 0-10 how much you personally trust each of the institutions I read out. 0 means you do not trust an institution at all, and 10 means you have complete trust. Firstly... READ OUT...

\section{No trust \\ at all}

Complete (Refu- (Don't

trust sal) know)

\begin{tabular}{|c|c|c|c|c|c|c|c|c|c|c|c|c|c|c|}
\hline B6 & $\begin{array}{l}\text {...[country]'s } \\
\text { parliament? }\end{array}$ & 00 & 01 & 02 & 03 & 04 & 05 & 06 & 07 & 08 & 09 & 10 & 77 & 88 \\
\hline B7 & $\begin{array}{l}\text {...the legal } \\
\text { system? }\end{array}$ & 00 & 01 & 02 & 03 & 04 & 05 & 06 & 07 & 08 & 09 & 10 & 77 & 88 \\
\hline B8 & ...the police? & 00 & 01 & 02 & 03 & 04 & 05 & 06 & 07 & 08 & 09 & 10 & 77 & 88 \\
\hline B9 & ...politicians? & 00 & 01 & 02 & 03 & 04 & 05 & 06 & 07 & 08 & 09 & 10 & 77 & 88 \\
\hline B10 & $\begin{array}{l}\text {...political } \\
\text { parties? }\end{array}$ & 00 & 01 & 02 & 03 & 04 & 05 & 06 & 07 & 08 & 09 & 10 & 77 & 88 \\
\hline B11 & $\begin{array}{l}\text {...the European } \\
\text { Parliament? }\end{array}$ & 00 & 01 & 02 & 03 & 04 & 05 & 06 & 07 & 08 & 09 & 10 & 77 & 88 \\
\hline B12 & $\begin{array}{l}\text {...the United } \\
\text { Nations? }\end{array}$ & 00 & 01 & 02 & 03 & 04 & 05 & 06 & 07 & 08 & 09 & 10 & 77 & 88 \\
\hline
\end{tabular}

B29 STILL CARD 11 Now thinking about the [country] government ${ }^{20}$, how satisfied are you with the way it is doing its job? Still use this card.

\section{Extremely \\ dissatisfied}

00

04

05

\begin{abstract}
06
\end{abstract}
$07 \quad 08$
Extremely (Refusal) (Don't satisfied know)

